NBS

UBLICATIONS

NBSIR 81-2436

\title{
Low Molecular Weight Leachables from Medical Grade Polymers
}

U.S. DEPARTMENT OF COMMERCE

National Bureau of Standards

National Measurement Laboratory

Center for Analytical Chemistry

Washington, DC 20234

Aprii 1981

Final Report

Issued Aprii, 1982

Prepared for

Food and Drug Administration Center of Medical Device Analysis

100 Bureau of Madical Devices

Rockviile, MD 20582 

LOW MOLECULAR VVEIGHT LEACHABLES

FROM MEDICAL GRADE POLYMERS

B. F. Howell, S. Chesler, L. Hilpert, and D. J. Reeder

U.S. DEPARTMENT OF COMMERCE

National Bureau of Standards

National Measurement Laboratory

Center for Analytical Chemistry

Washington, DC 20234

April 1981

Final Report

Issued April, 1982

Prepared for

Food and Drug Administration

Center of Medical Device Analysis

Bureau of Medical Devices

Rockville, MD 20852

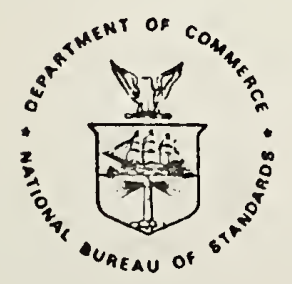

U.S. DEPARTMENT OF COMMERCE, Malcolm Baldrige, Secretary NATIONAL BUREAU OF STANDARDS, Ernest Ambler, Director 



\section{CONTENTS}

Page

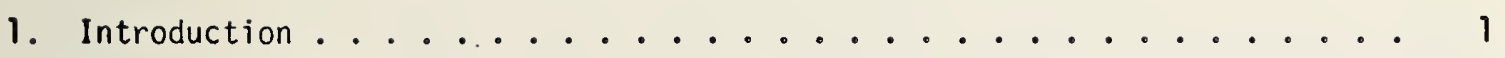

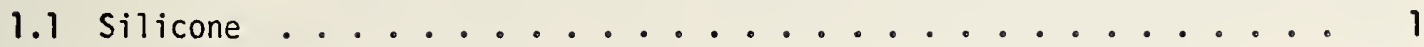

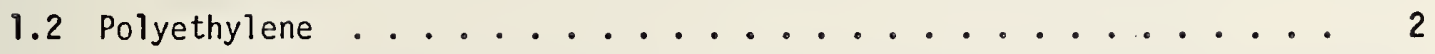

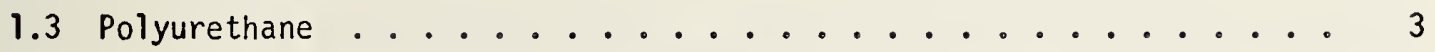

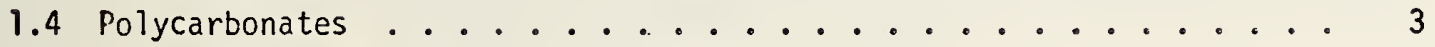

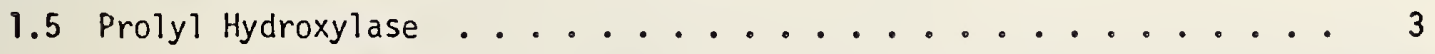

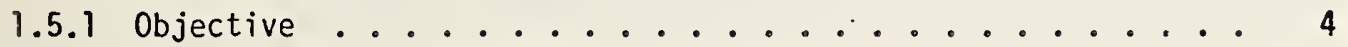

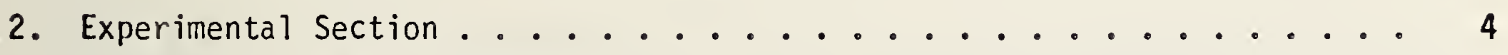

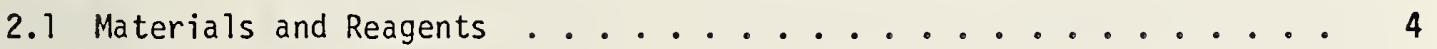

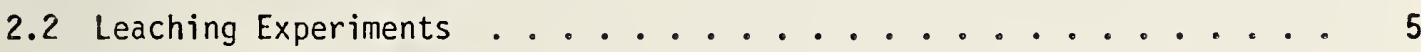

2.2.1 Polyethylene .................... 5

2.2.2 Polyurethane and Polycarbonate........... 5

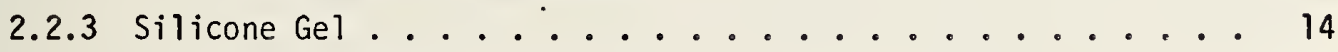

2.3 Prolyl Hydroxylase Studies . . . . . . . . . . . . . 22

2.3.1 Enzyme Preparation . . . . . . ........... 22

2.3.2 Protocollagen Substrate Preparation . . . . . . . . 22

2.3.3 Enzyme Assay . . . . . . . . . . . . . . 26

2.3.3.1 Conway Cells .............. 26

2.3.3.2 Microstills.............. 26

2.3.3.3 $\mathrm{CO}_{2}$ Assay ................ 27

2.3.3.4 Column Separation............. 27

2.3.4 Enzyme Purification ............... . . 28

2.3.4.1 Sepharose 4-B .............. 28

2.3.4.2 Dye Ligand Chromatography ... . . . . . . . 28

2.3.4.3 Affinity Chromatography ........... 28

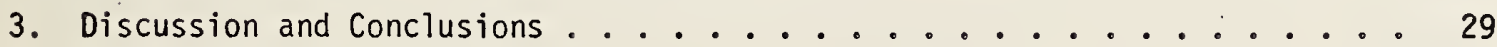

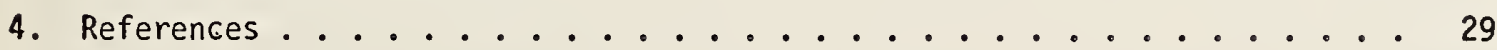




\section{LIST OF FIGURES}

Figure No.

Page

1 Total ion current profile vs. probe temperature for the methanol soluble portion of the aqueous leachate of polyethylene blood bag ...................... 6

2 Total ion current and $\mathrm{m} / \mathrm{z} 149,167$, and 279 (indicative of phthalate ester) vs. probe temperature for the methanol soluble portion of the aqueous leachate of polyethylene blood bag . . . . 7

3 Total ion current and $\mathrm{m} / \mathrm{z} 105,163$, and 77 vs. probe temperature for the methanol soluble portion of the aqueous leachate of polyethylene blood bag ............... 8

4 Mass spectrum at probe temperature of $40{ }^{\circ} \mathrm{C}$ corrected for background (polyethylene) leachate ............ 9

5 Mass spectrum at probe temperature of $26^{\circ} \mathrm{C}$ (polyethylene leachate). Unidentified materials ............ 10

6 Mass spectrum at probe temperature of $50^{\circ} \mathrm{C}$ (polyethylene leachate). Unidentified materials ............ 11

7 Gas chromatogram of polycarbonate leachate, methylene chloride

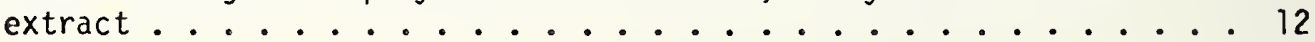

8 Gas chromatogram of polyurethane leachate, methylene chloride extract ................... 13

9 GC/MS total ion current profile, polyurethane leachate, methylene chloride extract ............. 15

10 Gas chromatogram of silicone leachate blank, methylene chloride

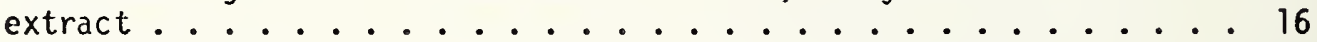

11 Gas chromatogram of silicone leachate, methylene chloride

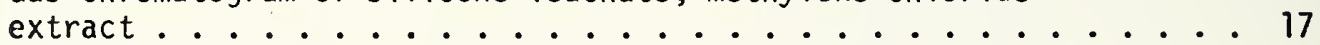

12 Total ion current, $\mathrm{m} / \mathrm{z} 73,147,207,221,281$ and 295 vs. probe temperature for silicone gel .................. 19

13 Mass spectrum at a probe temperature of $90{ }^{\circ} \mathrm{C}$ silicone gel leachate..........................20

14 (upper) Total ion current and $\mathrm{m} / \mathrm{z} 149 \mathrm{vs}$. probe temperature for silicone gel leachate. (lower) Mass spectrum at probe temperature of $45{ }^{\circ} \mathrm{C}$ showing the presence of ions characteristic of phthalate

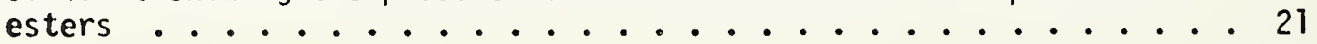

15 Total ion current vs. probe temperature for silicone gel . . . . 23

16 Total ion current and selected mass chromatograms for silicone gel . 24

17 Mass spectrum at probe temperature of $50^{\circ} \mathrm{C}$ (silicone gel) . . . 25 


\title{
Low Molecular Weight Leachables from Medical Grade Polymers
}

\author{
B. F. Howell, S. Chesler, L. Hilpert, and D. J. Reeder \\ Center for Analytical Chemistry \\ National Bureau of Standards \\ Washington, DC 20234
}

Four medically important polymeric materials (silicone polymer from mammary prostheses, polyurethane, polyethylene, and polycarbonate) were placed in contact with water for time periods ranging from four hours to seven days. Substances leaching into water were separated by extraction with methylene chloride, or by evaporation of water, and identification of species in the leachate was attempted by a number of analytical techniques, with extensive use of combined gas chromatography/mass spectrometry (GC/NS). Low molecular weight fragments of dimethylsiloxane were identified from mammary prosthesis gel. Spectra are also included for leachate from the other three polymers; identification of these compounds is still in process.

Prolyl hydroxylase and tritium-labeled protocollagen substrate were prepared from chick embryos, and an enzyme activity assay system was developed with use of Bio-Rad AG $50 W-X 8$ cation exchange resin. No effect on enzyme activity was seen when silicone gel leachate was added to the assay mixture.

Key words: enzymatic assay, gas chromatography/mass spectrometry, leachables, mammary prosthesis, polymeric implants, prolyl hydroxylase.

\section{Introduction}

Because of their low cost and versatility, plastics of various kinds have found increasing application for medical purposes; e.g., polyethylene blood bags, polycarbonate centrifuge bowls, extracorporeal shunt tubing and ultrafiltration membranes. In addition, implantation of devices for cosmetic purposes or to sustain life is done 2-3 million times annually with a variety of substances being employed as implant materials. Implanted materials include stainless steel and high density polyethylene for femur prostheses, siloxane for heart valve poppets, silicone polymers for breast prostheses, and a host of other materials for a wide variety of purposes [1] $]^{1}$.

\subsection{Silicone}

Of the many plastic materials which have been employed for implant purposes, silicone polymers have proven to be among the most biologically inert [2]. However, problems are still being encountered with mammary prostheses which consist of silicone gel enclosed in a silicone film. For these, capsular contraction, caused by collagen buildup around the implant, has sometimes been a cause for complaint. Work

'Figures in brackets indicate the literature references at the end of this paper. 
has been done to elucidate the causes of encapsulation but without shedding much light on the nature of the problem. For example, recent work at Battelle, Columbus [3], investigated low molecular weight leachables from silicone gel mammary augmentation devices. Using ethanol and tetrahydrofuran as solvents, the Battelle researchers identified methyl and phenyl-silicones but no non-silicone materials except for phthalate esters, which may have been an artifact. Their work included examination of the rheological properties of the gels, with complex modulus and viscosity measurements.

Medical grade silicone gels originating from linear or branched polysiloxanes with methyl groups alone or with phenyl and/or hydroxyl groups on the silicon atom can be obtained in quite pure form. Since condensation polymerization accelerators are usually simple acids or bases, and cross-linking agents are peroxides such as benzoyl peroxide, dichlorobenzoyl peroxide, dicumyl peroxide or tert-butyl cumyl peroxide [4], complex organic leachables are not expected to be present. Likewise, fillers such as titanium dioxide are not present.

\subsection{Polyethylene}

Polyethylene may be prepared by a variety of methods depending on the properties desired for specific applications. Medical grade polyethylene, such as that used in blood bags, is expected to have low amounts of organic extractables. However, production of "clean" polyethylene is somewhat more difficult than for silicone polymers. A variety of additives may be used to retard degradation. Peroxides, carbonyl compounds, and stabilizers in a variety of forms can be present in polyethylene. Recent work by Schabron and Fenska [5] demonstrated the capability of extracting the three most commoniy used hindered-phenyl-type antioxidants added in the manufacturing of polyethylene: 2,6-di-tert-butyl-4-methylphenol (BHT), octadecyl 3,5-di-tert-buty 1-4-hydroxy-hydrocinnamate (Irganox 1076) ${ }^{2}$ and tetrakis

[methylene 33,5 -di-tert-buty 1-4-hydroxyhydrocinnamate)] methane (Irganox 1010) ${ }^{2}$. In this analytical procedure, a $2 \mathrm{~g}$ sample of polyethylene was dissolved in decalin (decahydronaphthalene) at $110^{\circ} \mathrm{C}$ and then stirred as the solution cooled and the polyethylene precipitated. The filtrate was analyzed by normal-phase high performance liquid chromatography (HPLC) on a $\mu$-Porasil column with the mobile phase consisting of a heptane to methylene chloride gradient.

Other methods of chemical analyses recently have been reported for additives in polyethylene. Lehotay, et al. [6] used thin layer chromatography (TLC), HPLC, gas chromatography (GC) and mass spectrometry (MS) to separate and detect polyethylene additives. Their extraction scheme used Soxhlet extraction of $100 \mathrm{~g}$ of powdered polyethylene with $500 \mathrm{~mL}$ of $\underline{n}$-hexane (or chloroform). The fractions were filtered and evaporated and soluble fractions of low molecular weight polymers were removed by methanol extraction. Unfortunately, detection limits for each method of analysis were not provided.

Qualitative studies of water leaching of polyethylene were reported as early as 1976 by Kandpal, et a 1. [7]. They reported that water contact with polyethylene containers for even one hour at room temperature was sufficient to leach watersoluble low molecular weight compounds having hydroxyl, carboxyl or carbonyl groups which caused measurable decreases in surface tension of the leachate. Further storage of the water ( 6 hours or longer) in the containers resulted in strong absorbance in the ultraviolet region $(200-300 \mathrm{~nm})$. However, further identifications of the leachates were not reported in this publication.

2 In this report, in order to describe procedures adequately, it has occasionally been necessary to identify commercial products and equipment. In no case does such identification imply NBS reconmendation or endorsement, nor does it imply that the item identified is necessarily the best available for the purpose. 


\subsection{Polyurethane}

A wide range of medical grade polymers may be obtained by reacting polyesters, polyethers or polyols with diisocyanates. Resulting polyurethanes may have properties ranging from rubber-like resins to foams, to clear, flexible sheeting [4]. As described in a recent publication, medical-grade polyurethane blood bags were fabricated from polyurethane prepared from a polyether diol and 4,4 $4^{\circ}$-diphenylmethane diisocyanate (MDI). When the blood bags were autoclaved $\left(121^{\circ} \mathrm{C}\right.$ ) in an aqueous solution for 2 or $5 \mathrm{hr}$, an aromatic amine analog of MDI was obtained [8]. This analog was chemically identified by GC, MS, and nuclear magnetic resonance spectroscopy (NMR) as 4,4'-diaminodiphenylmethane, also known as 4,4'-methylenedianiline (MDA).

In another study [9], extraction of an unspecified grade of polyurethane with toluene has been employed for characterization of low molecular weight oligomers. The extraction solvent was evaporated under nitrogen. The residue, dissolved in tetrahydrofuran, was subjected to field desorption mass spectrometry (FD-MS). FD-MS revealed cyclic esters (unit $m w=200$ ) derived from adipic acid and 1,4-butanediol, and related cyclic esters. The polyurethane was shown to be derived from the incorporation of one and two 4,4'-diphenylmethane diisocyanate units into a basic cyclic polyurethane with a molecular weight of 200 . Solvent extraction allowed isolation of residual monomers and solvents, chemical additives, and low molecular weight oligomeric material.

Based on the above reports, it is expected that polyurethane may be the richest source of extractable materials.

\subsection{Polycarbonates}

Polycarbonates are essentially linear thermoplastic polyesters of carbonic acid with aliphatic or aromatic dihydroxy compounds and have numerous applications in the medical and dental fields. They may be synthesized by a variety of procedures, but most synthetic methods employ aromatic dihydroxy compounds such as 2,2' -bis (hydroxyphenyl-)propane, commonly known as bisphenol A. Condensation may be achieved by a variety of procedures, involving organic solvents such as pyridine or methylene chloride. The mechanical properties of medical grade polycarbonate make it suitable for durable appliances such as centrifuge bowls, blood separators, syringes, and various receptacles. Such articles may be sterilized by autoclaving at $121{ }^{\circ} \mathrm{C}$. Polycarbonate materials have been more widely used in dental prostheses than in implantable prostheses.

A search of the recent literature failed to reveal any studies that sought to identify leachable products from polycarbonate materials.

\subsection{Prolyl Hydroxylase}

The enzyine, prolyl hydroxylase (EC 1.14.11.2; proline 2-oxoglutarate dioxygenase), which hydroxylates prolyl residues in newly synthesized collagen, is essential in the biosynthesis of collagen. In fact, hydroxyproline is found in vertebrate tissues almost exclusively in collagen. Changes in prolyl hydroxylase activity have been studied in a number of experimental and pathological states. Of particular interest is the observation that enhanced collagen synthesis has been detected in human tissue in contact with a variety of polymeric breast implants. In some cases, hardening of the collagenous scar tissue was sufficient to require surgical removal of the prosthesis. 
It is postulated that prolyl hydroxylase is stimulated by chemical agents released from polymeric implants, thus promoting excess collagen formation. Such stimulating agents may be from unreacted monomers, from various additives, or from substances introduced into the device after it is prepared for implantation.

\subsubsection{Objective}

Work at NBS was focused on providing the Center for Medical Device Analys is, Bureau of Medical Devices with data on the identification of low molecular weight leachables from polymeric prostheses and medical devices. Because physiological systems are mostly aqueous in composition, we chose to employ water leaching to study the four polymeric materials described above. Extension to saline leaching, followed by more complex leaching solutions, (e.g., complex salts, pure proteins or serum) is anticipated for future studies.

In a parallel investigation we focused our efforts on establishing a reliable assay for prolyl hydroxylase as well as investigating methods for purification of this enzyme. Preliminary work has been performed to test the influence of low molecular weight leachables on the enzymic activity.

\section{Experimental Section}

\subsection{Materials and Reagents ${ }^{2}$}

The four types of polymeric materials obtained for study were polyurethane, polyethylene, polycarbonate, and silicone elastomer and gel. A list of the materials, descriptions, and the suppliers follows:

1. Polyethylene - sterile blood freezing bags, Style 8000-2, Lot 4016, Delmed Corp., Holbrook, MA 02343

SRM 1482, MW 13,600, National Bureau of Standards

SRM 1484, MW 119,600, National Bureau of Standards

2. Polyurethane $-0.5 \mathrm{~cm}$ pellets, 2363-80A, Lot 3091R, Upjohn Co., North Haven, Conn. 06473

3. Polycarbonate- $0.5 \mathrm{~cm}$ pellets, Hemonetics, Braintree, MA 02184

4. Silicone - Q7-2159A-cured gel, lot No. H020059 \#22, prosthes is envelopes Elastomer \& (Prod. \#MDF0077) Lot \#HIl-8313; silastic R gel filled mammary Gel prosthesis (200 cc size) Lot No. H099686; silastic R block, $7 \times 25 \mathrm{~cm}$, Lot No. H109013, \#802 PN96800-02; all from Dow-Corning Corp, Midland, Mich. 48640

Chick embryos were the source of prolyl hydroxylase and substrate used to perform enzymatic assays. The embryo-containing eggs were obtained from Truslow Farms, Chestertown, MD. Tritium labeled proline, $L-\left[3,4-{ }^{3} \mathrm{H}\right]-\mathrm{HN}-\mathrm{CH}_{2} \mathrm{CH}_{2} \mathrm{CH} 2 \mathrm{CHCOOH}$, was obtained from New England Nuclear Co., Boston, MA 02118, as was carbon-14 labeled $\alpha$-ketoglutaric acid. All other reagents were of the highest quality commercially obtainable. 


\subsection{Leaching Experiments}

\subsubsection{Polyethylene}

One hundred $\mathrm{mL}$ of water processed for use in high performance liquid chromatography (HPLC) was added to each of five polyethylene blood bags and these were placed horizontally on a slowly rotating mixing table. Before filling, tubes connected to the bags were snipped off and bag openings were closed with clamps. Nevertheless, water leaked from some of the bags and left a white powder residue where drops evaporated.

In a follow-up experiment, ten polyethylene blood bags were leached with $20 \mathrm{~mL}$ portions of HPLC-grade water for one week. The $20 \mathrm{~mL}$ portions were pooled and water was evaporated at $30^{\circ}$ on a rotary evaporator under vacuum. A few milligrams of a light tan powder remained. The manufacturer was consulted about the possible nature of this material. It could not be an agent to prevent adherence of plastic layers or a mold release agent since such substances were not used in the manufacturing process. Suggestions were made by the manufacturer to check for polymers of ethylene oxide, ethylene glycol or ethylene chlorohydrin. Ten to $25 \mathrm{ppm}$ of these three substances is a permissible load, according to the manufacturer.

Analysis by mass spectrometry of a methanol soluble portion of the tan powder did not yield any good matches to compounds present in the NBS/NIH/EPA mass spectrometry data base. The spectra are consistent with the presence of an octyl phthalate, a compound with a benzoyl group and other unknown constituents. Figures 1-6 present the mass spectral data.

In considering that the contaminating powder was talcum powder (because of its use in dusting polyethylene surgical gloves) samples of the powder were subjected to atomic absorption spectrometry (AAS) and infrared analysis (IR). Specifically, AAS was used to analyze for the presence of zinc (from zinc stearate in talcum powder). The results indicated the presence of $\sim 0.03 \mathrm{ng} \mathrm{Zn} / 20 \mu \mathrm{L}$ sample, or $1.6 \mu \mathrm{g}$ in a single blood bag, implying that zinc stearate was not present to any great extent. Likewise, IR spectra showed no resemblence to a stearate-containing molecule.

\subsubsection{Polyurethane and Polycarbonate}

For the first series of studies, polyurethane and polycarbonate were leached at room temperature by weighing $20 \mathrm{~g}$ quantities into separate Erlenmeyer flasks, adding $20 \mathrm{~mL}$ of HPLC-grade water to each flask, covering with aluminum foil to prevent loss of water, and shaking at room temperature for one week. At the end of the week, water from each beaker was filtered through $\# 1$ Whatman filter paper and $0.3 \mu \mathrm{m}$ Millipore filters and then extracted with $20 \mathrm{~mL}$ of methylene chloride which was evaporated to $\sim 1 \mathrm{~mL}$ under a nitrogen stream. Samples thus concentrated were examined by gas chromatography. In addition, mass spectrometry was used for identification of constituents of the polyurethane extracts.

Gas chronlatography employed a 3 percent Dexsil 300 packed column $(1.8 \mathrm{~m} \times 2 \mathrm{~mm})$. The injector and detector temperatures were $250{ }^{\circ} \mathrm{C}$ with an initial column temperature of $70^{\circ} \mathrm{C}$ for $4 \mathrm{~min}$, followed by an increase of $8{ }^{\circ} \mathrm{C} / \mathrm{min}$ until the final temperature was achieved, then held for $16 \mathrm{~min}$. Several small peaks were observed in the polycarbonate leachate (Fig. 7).

An additional leaching technique was employed for polyurethane. Ten gram samples (to which $10 \mathrm{~mL}$ water were added) were leached at $56^{\circ}$ for 75 hours. Twentyfive $\mathrm{mL}$ of methylene chloride were used to extract each $10 \mathrm{~mL}$ of water. 


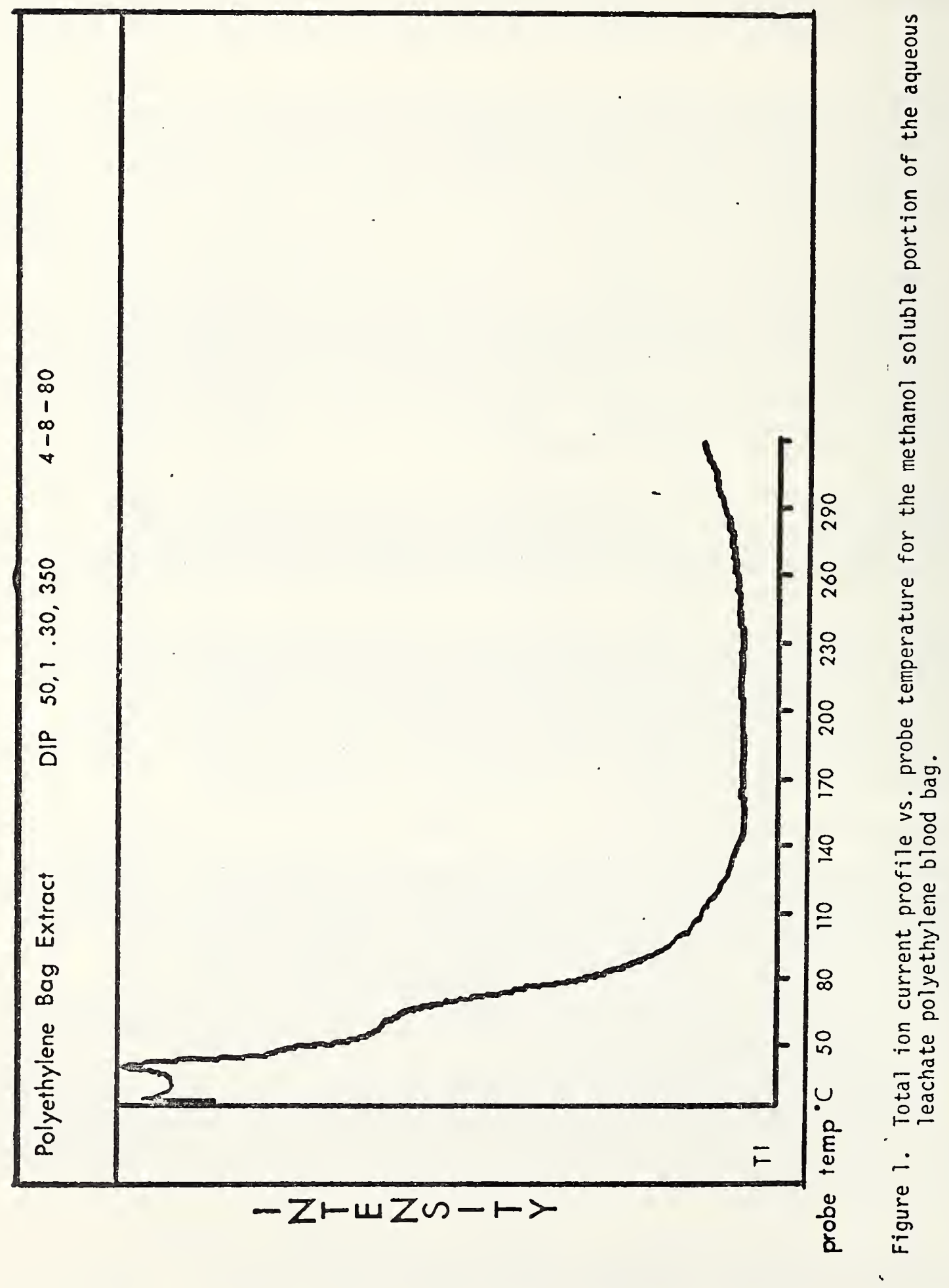




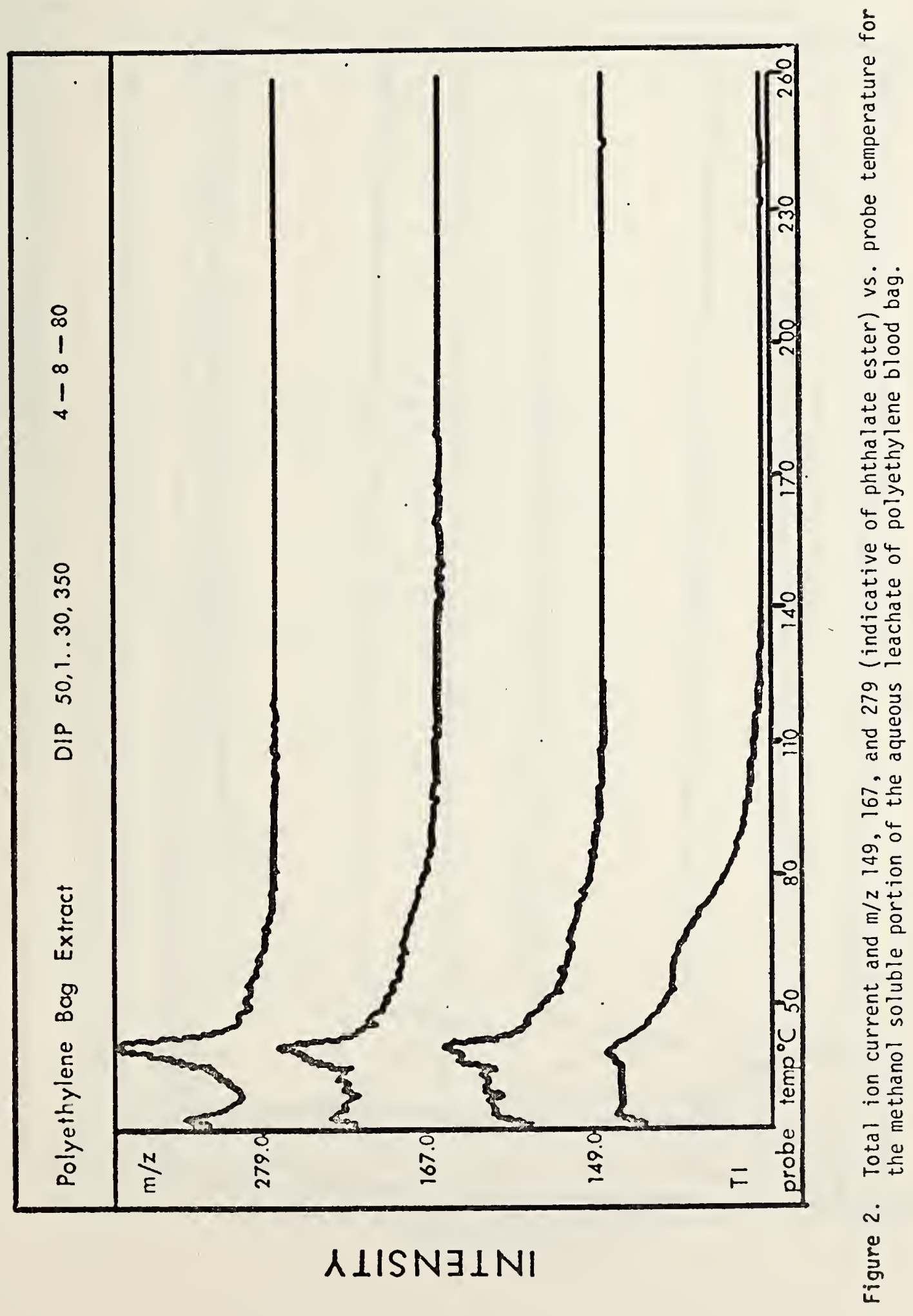




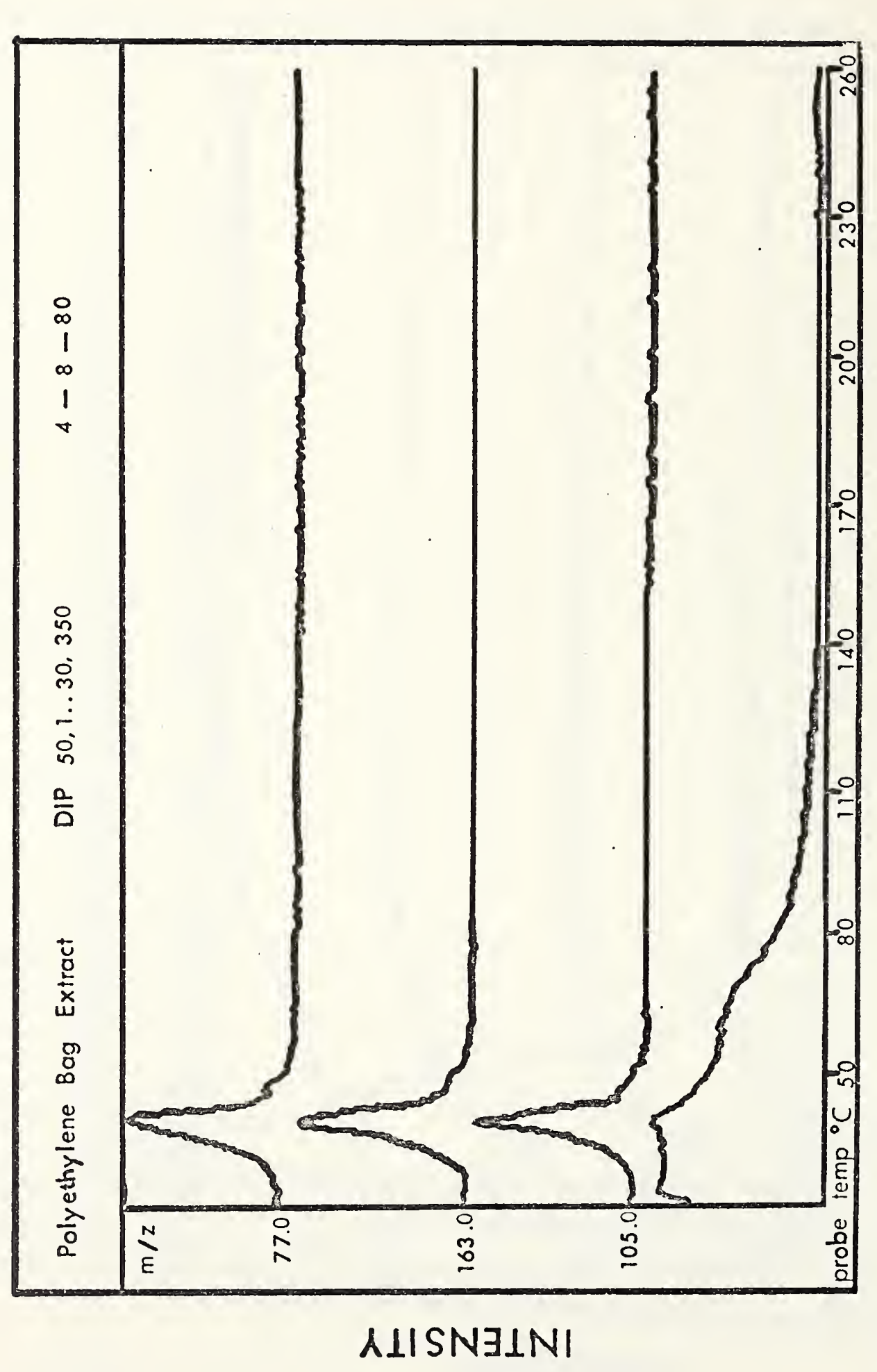

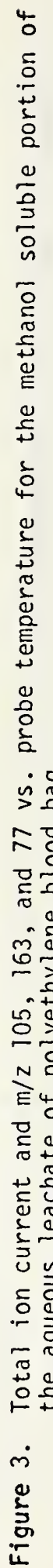




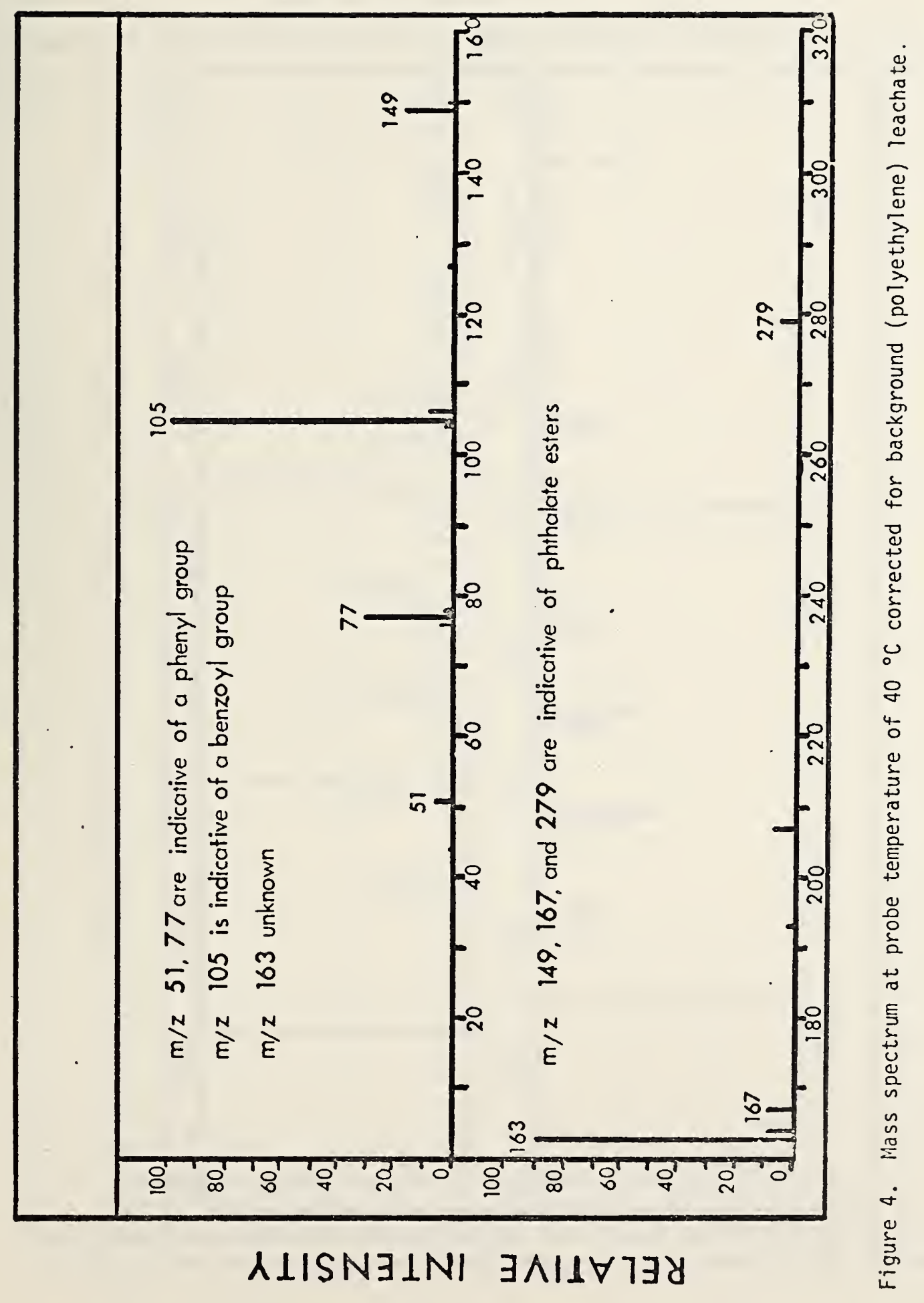




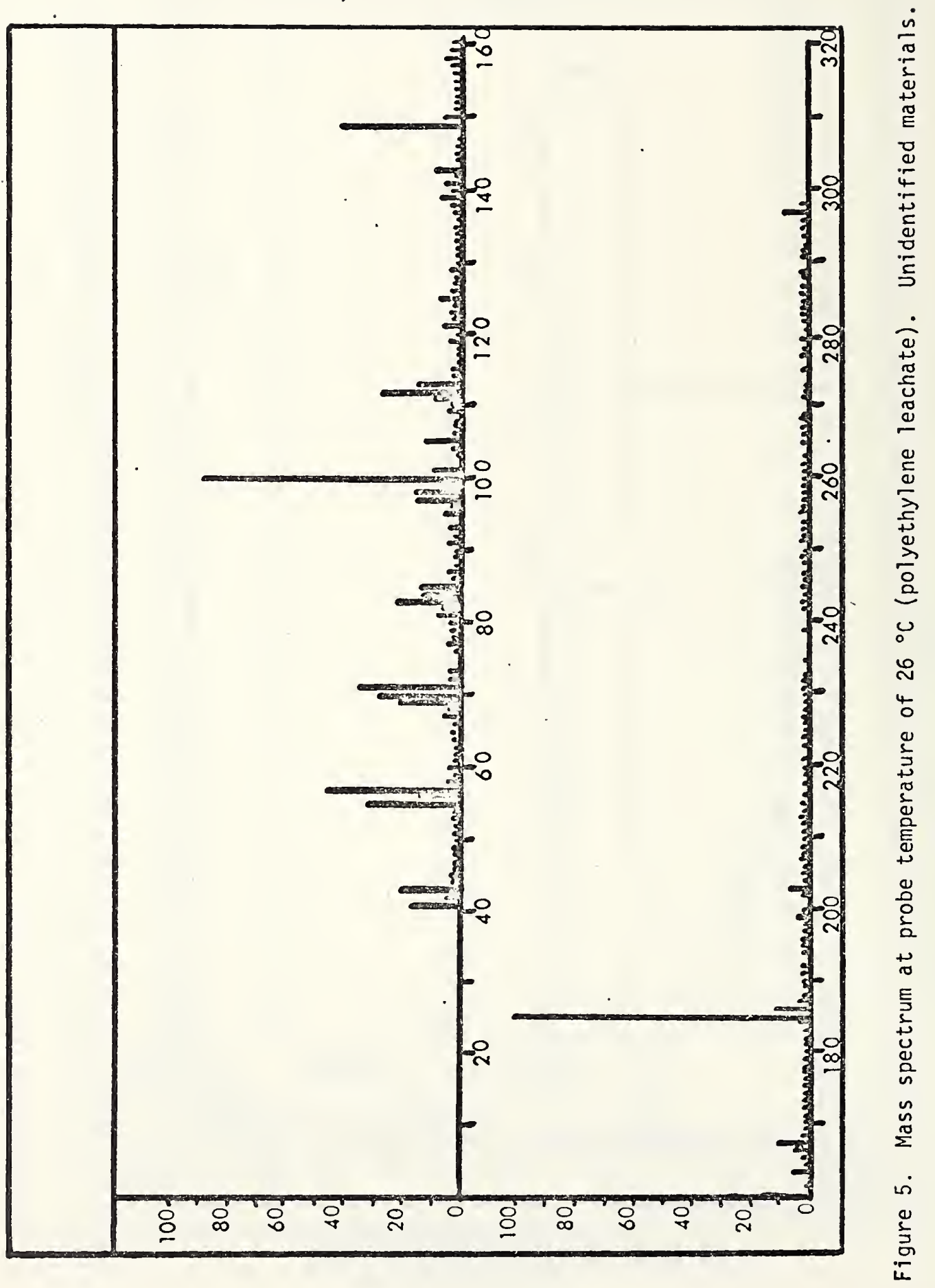




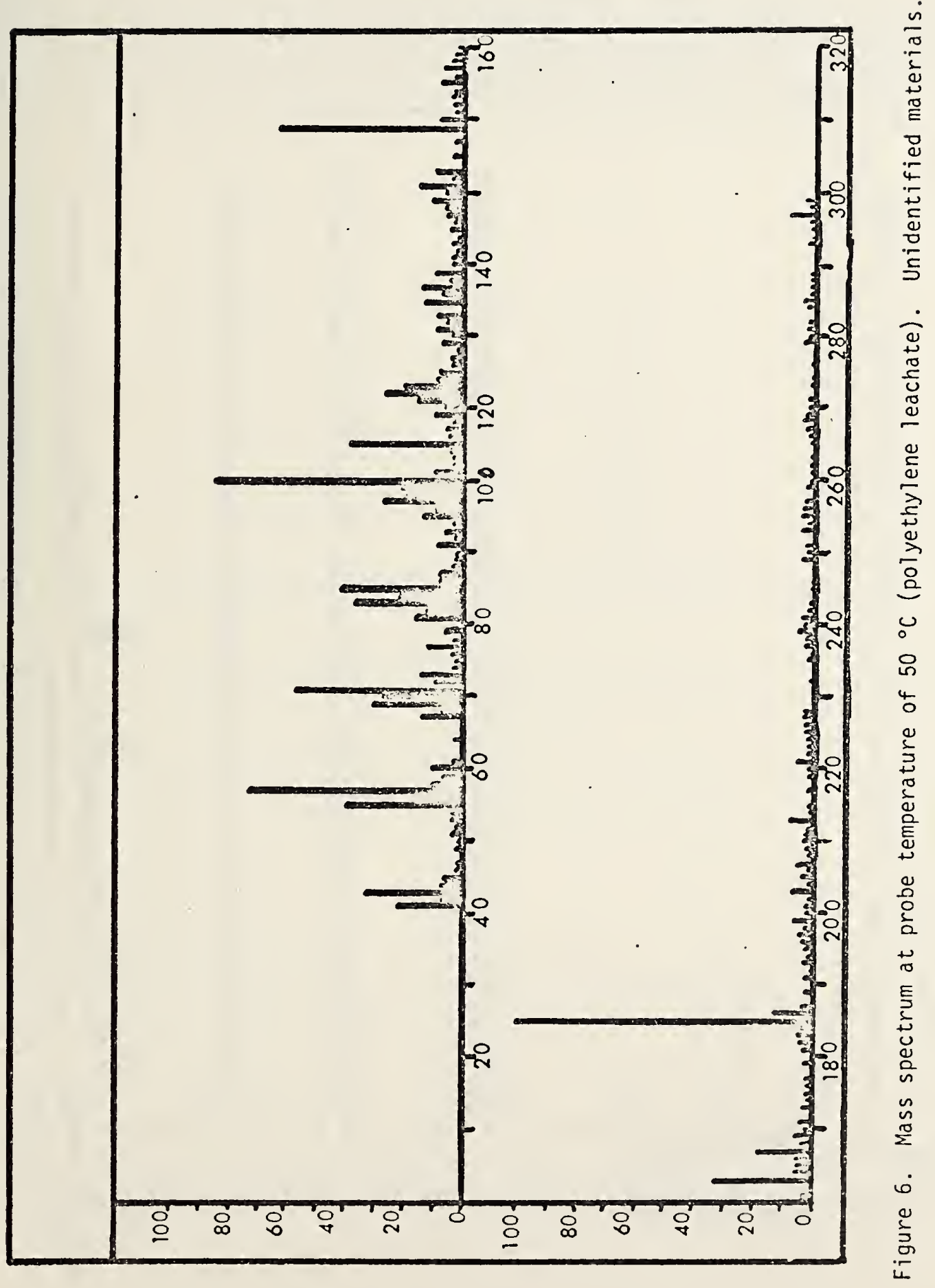




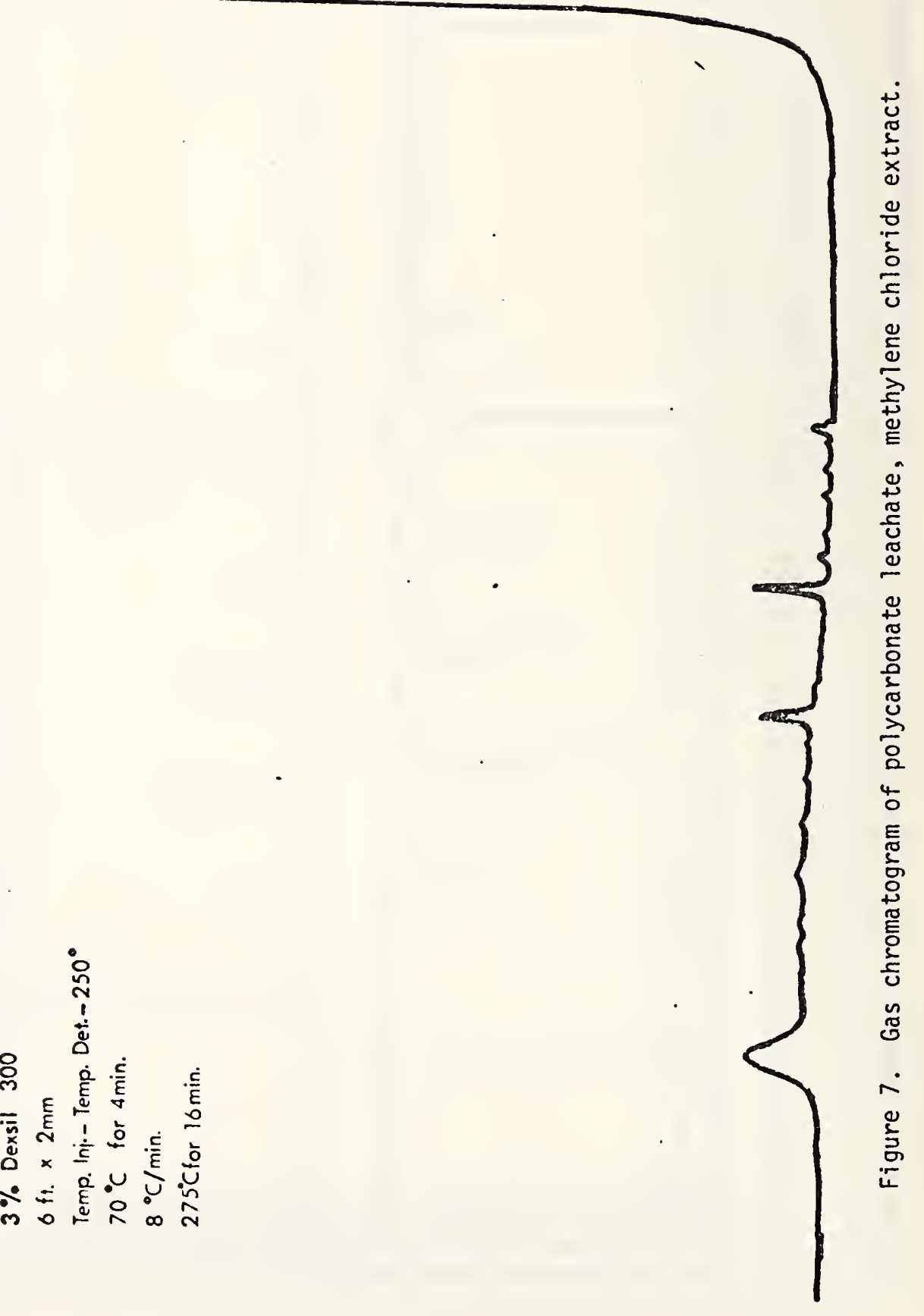


Methylene chloride extracts were evaporated to $\sim 50 \mu \mathrm{L}$ under a stream of dry nitrogen and one to two $\mu \mathrm{L}$ aliquots were analyzed by GC. Chromatographic separations were carried out on a $30 \mathrm{~m} \mathrm{SE-30} \mathrm{fused} \mathrm{silica} \mathrm{capillary} \mathrm{column.} \mathrm{The} \mathrm{GC} \mathrm{column} \mathrm{was}$ temperature progranmed from $80^{\circ} \mathrm{C}$ to $250^{\circ} \mathrm{C}$ at a rate of $8 \% / \mathrm{min}$. In this procedure (and in comparison with the previous leaching technique) four major peaks were observed (Fig. 8).

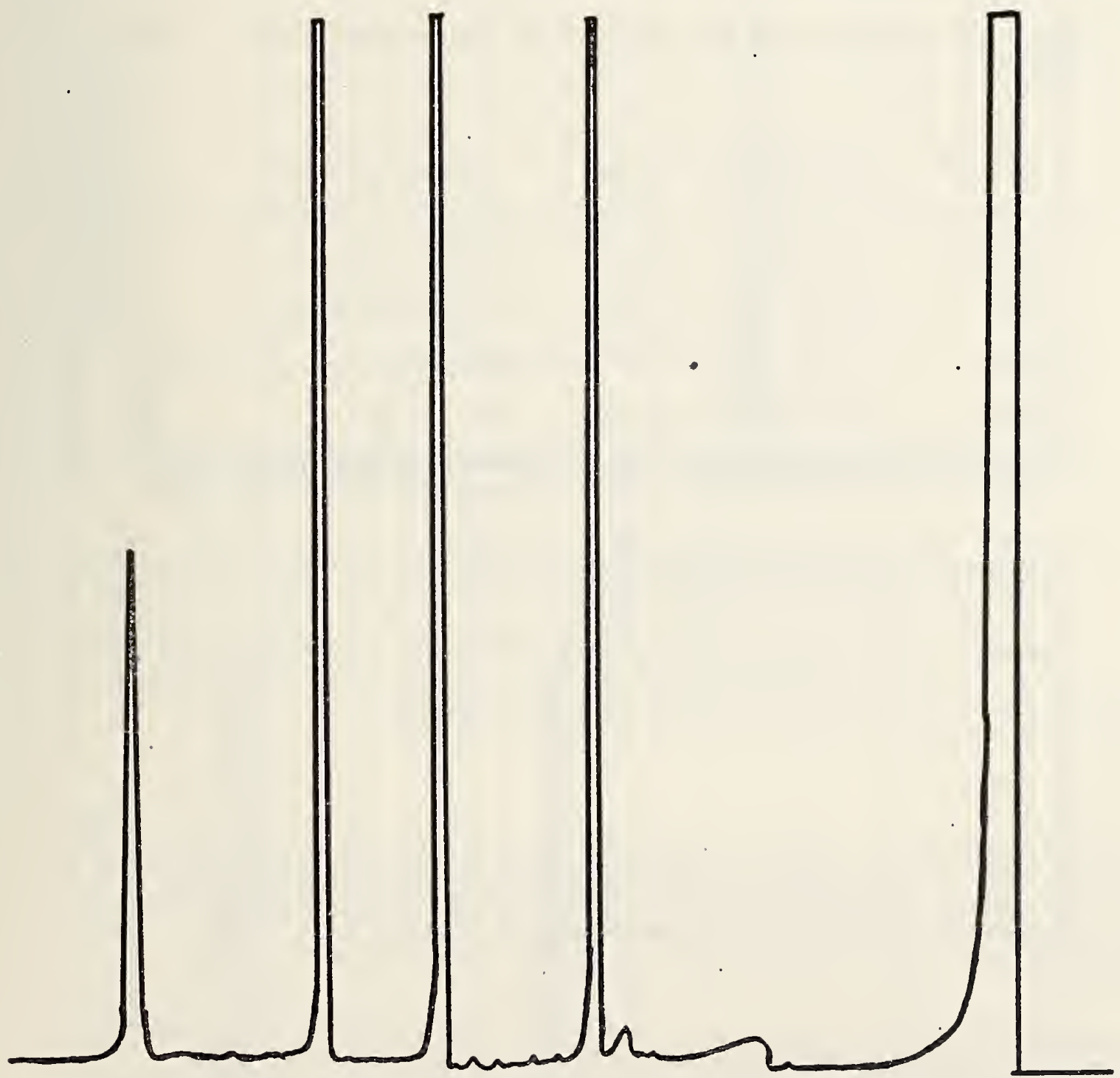

Figure 8. Gas chromatogram of polyurethane leachate, methylene chloride extract. 
Based on this separation, a similar SE-30 column was used in the GC inlet to the mass spectrometer. Mass spectra were scanned repetitively every $2.5 \mathrm{~s}$ over the course of the GC run. Peak identifications were made based on a comparison of the mass spectra with those in the NBS/NIH/EPA Mass Spectral Data Base and confirmed by manual interpolation. Peaks where no identification was made are listed as UNK. These data appear in Fig. 9 and Table 1.

Table 1. Peak Identifications from GC/MS Analys is of Polyurethane Extract U-1 (FRN 6232)

\begin{tabular}{lll}
\hline Peak RT & Five Most Intense Ions & \multicolumn{1}{c}{ Identification } \\
\hline 3.3 min. & $36,43,56,41,85$ & ethylene urea \\
7.5 & $88,73,87,57,101$ & $\begin{array}{l}\text { 2-ethylhexanoic acid } \\
14.4\end{array}$ \\
$11,73,100,85,55$ & unk \\
18.0 & $105,135,75,45,107$ & unk \\
21.2 & $149,223,150$ & $\begin{array}{l}\text { phthalate ester (also } \\
\text { seen in blank) }\end{array}$ \\
21.6 & $71,73,55,85,100$ & unk \\
27.5 & $71,73,55,85,100$ & unk \\
& $71,73,55,85,100$ & unk
\end{tabular}

Unknowns at $14.4,21.2,21.6$, and $27.5 \mathrm{~min}$ are clearly related.

\subsubsection{Silicone Gel}

For silicone samples, $10 \mathrm{~g}$ of the silicone gel were extracted with $10 \mathrm{~mL}$ of HPLC grade water at $56^{\circ} \mathrm{C}$ for 48 hours and room temperature for an additional 96 hours. The aqueous leachate was decanted into a $250 \mathrm{~mL}$ separatory funnel and $20 \mathrm{~mL}$ of $\mathrm{CH}_{2} \mathrm{Cl}_{2}$. The methylene chloride extract was reduced in volume under a stream of dry nitrogen to $21.5 \mathrm{~mL}$. Both silicone gel $(\mathrm{S}-1)$ extract and blanks were treated similarly.

For gas chromatographic analysis, run conditions were similar to those used for polycarbonate and polyurethane, except that a SE-52 capillary column was used. Results are shown in Figures 10 and 11 . The chromatographic traces for the silicone gel are considerably more complex than those for the polycarbonate and polyurethane. 


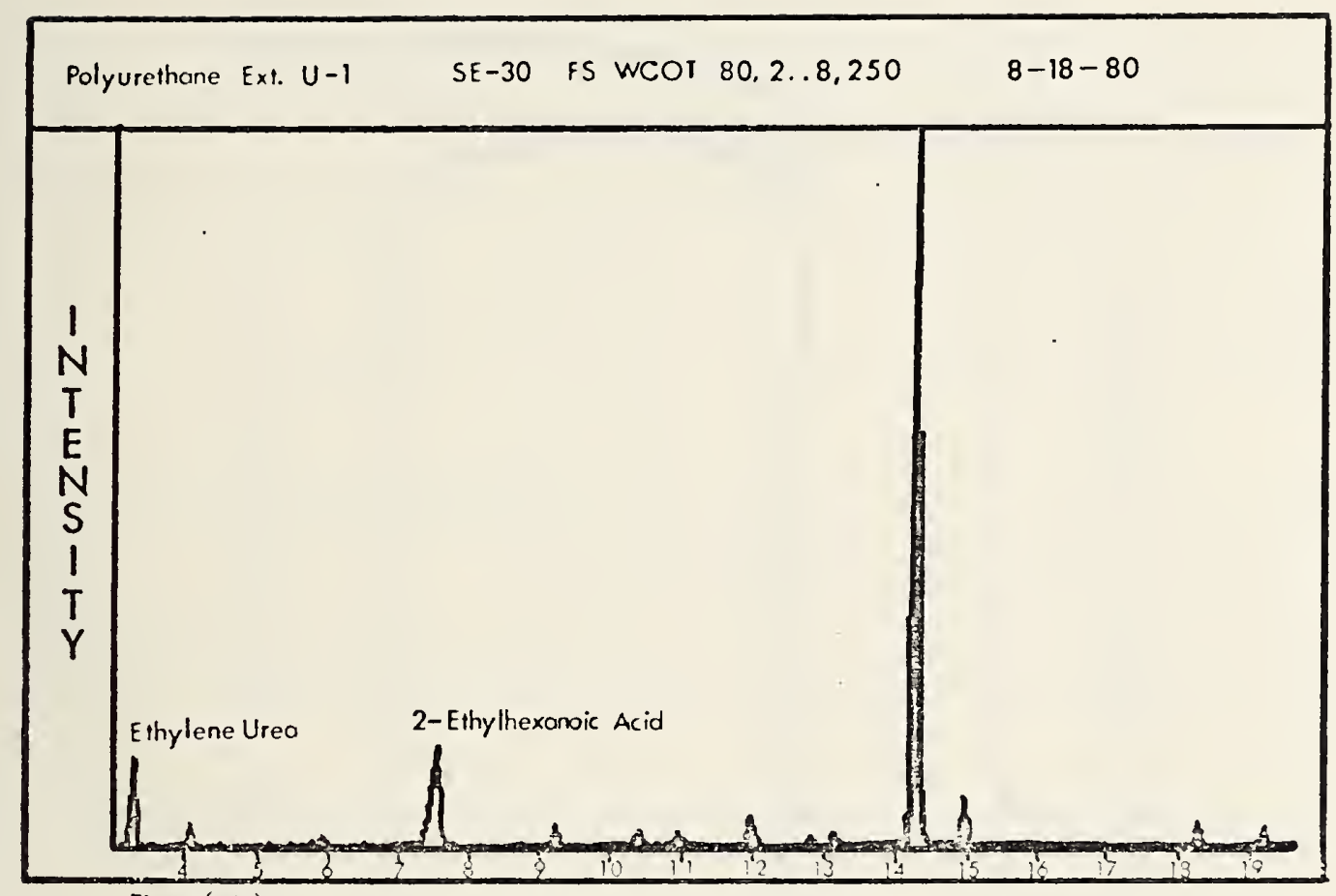

Time (min)

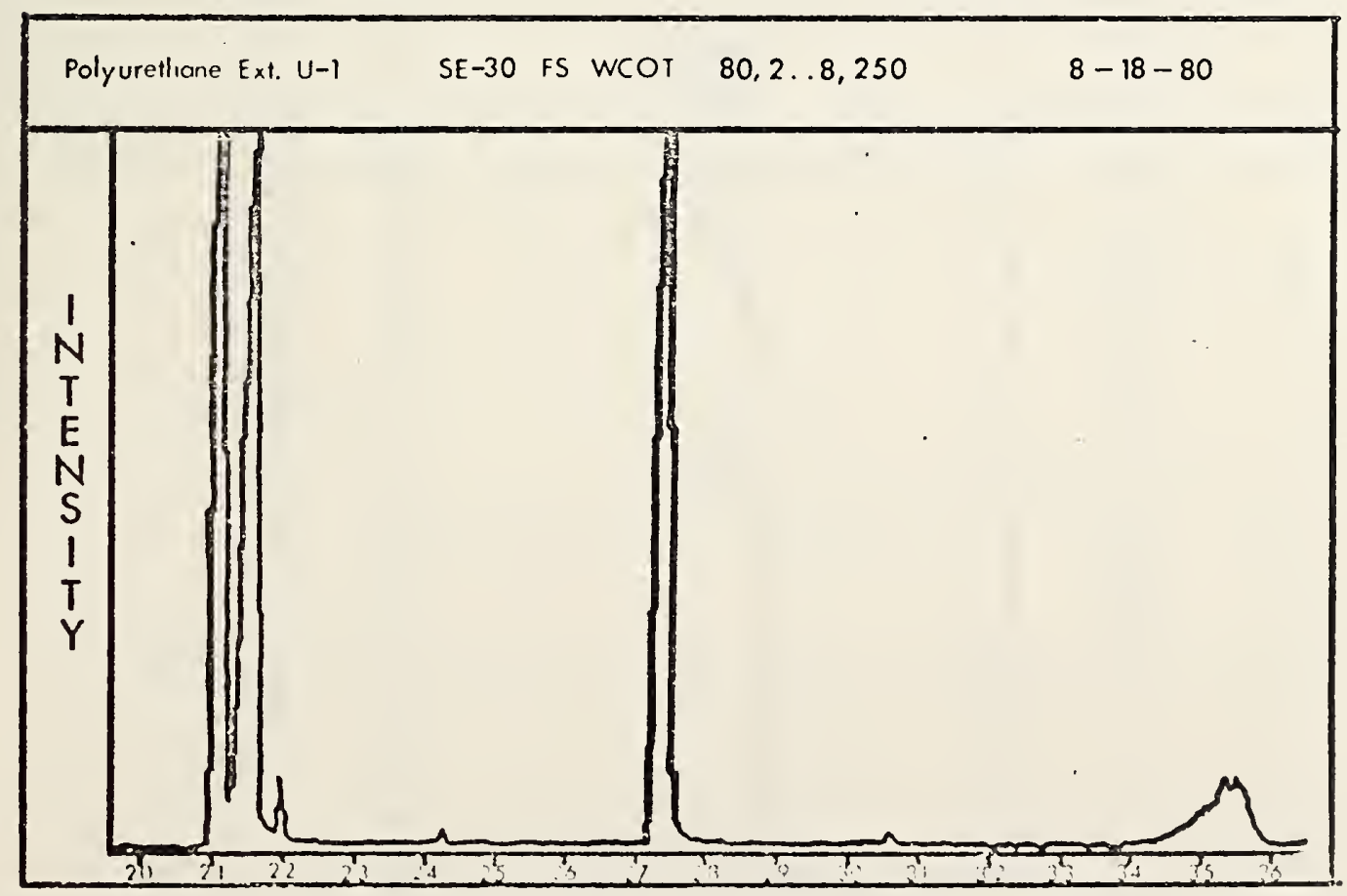

Figure 9. GC/MS total ion current profile, polyurethane leachate, methylene chloride extract. 


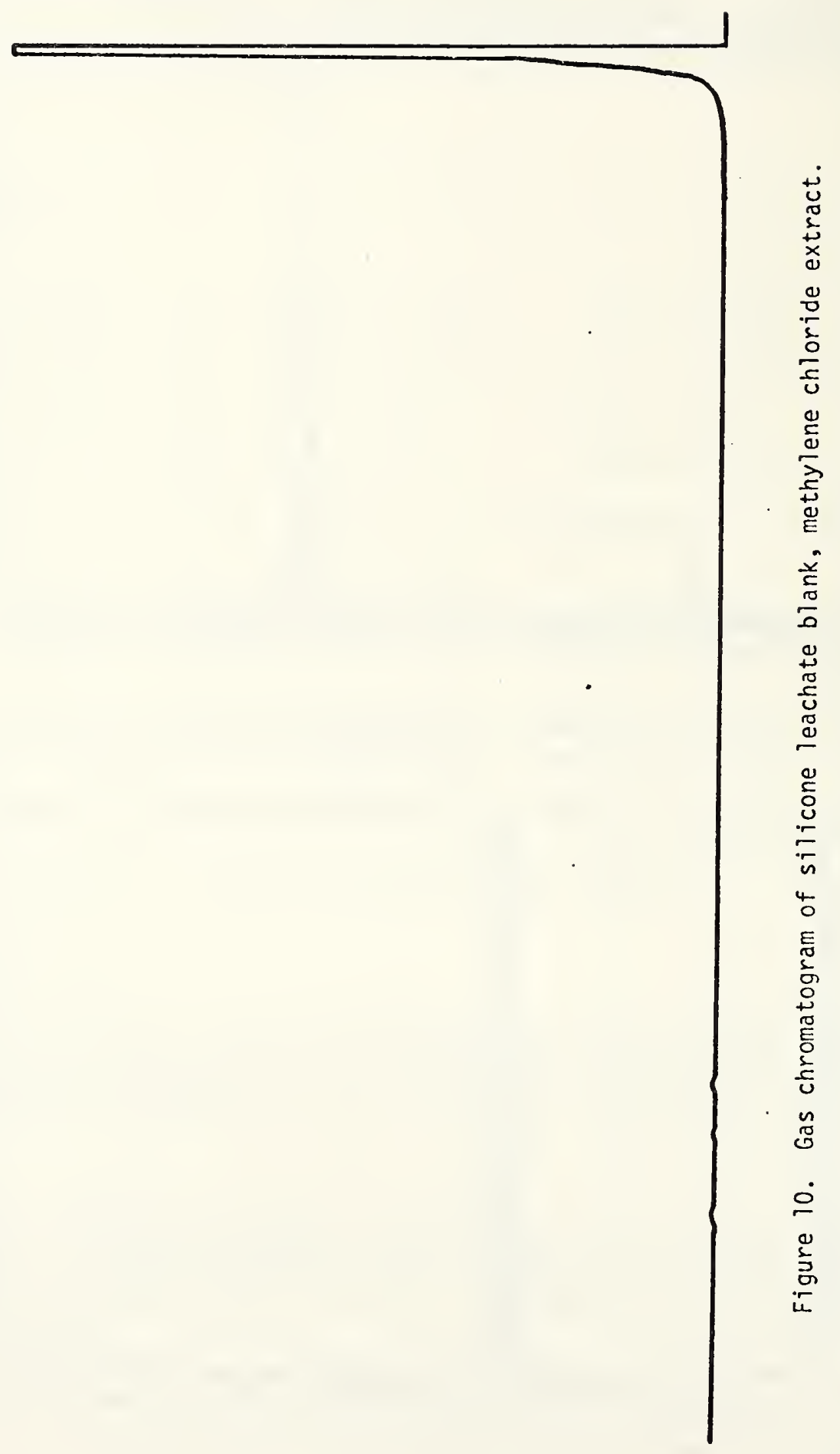




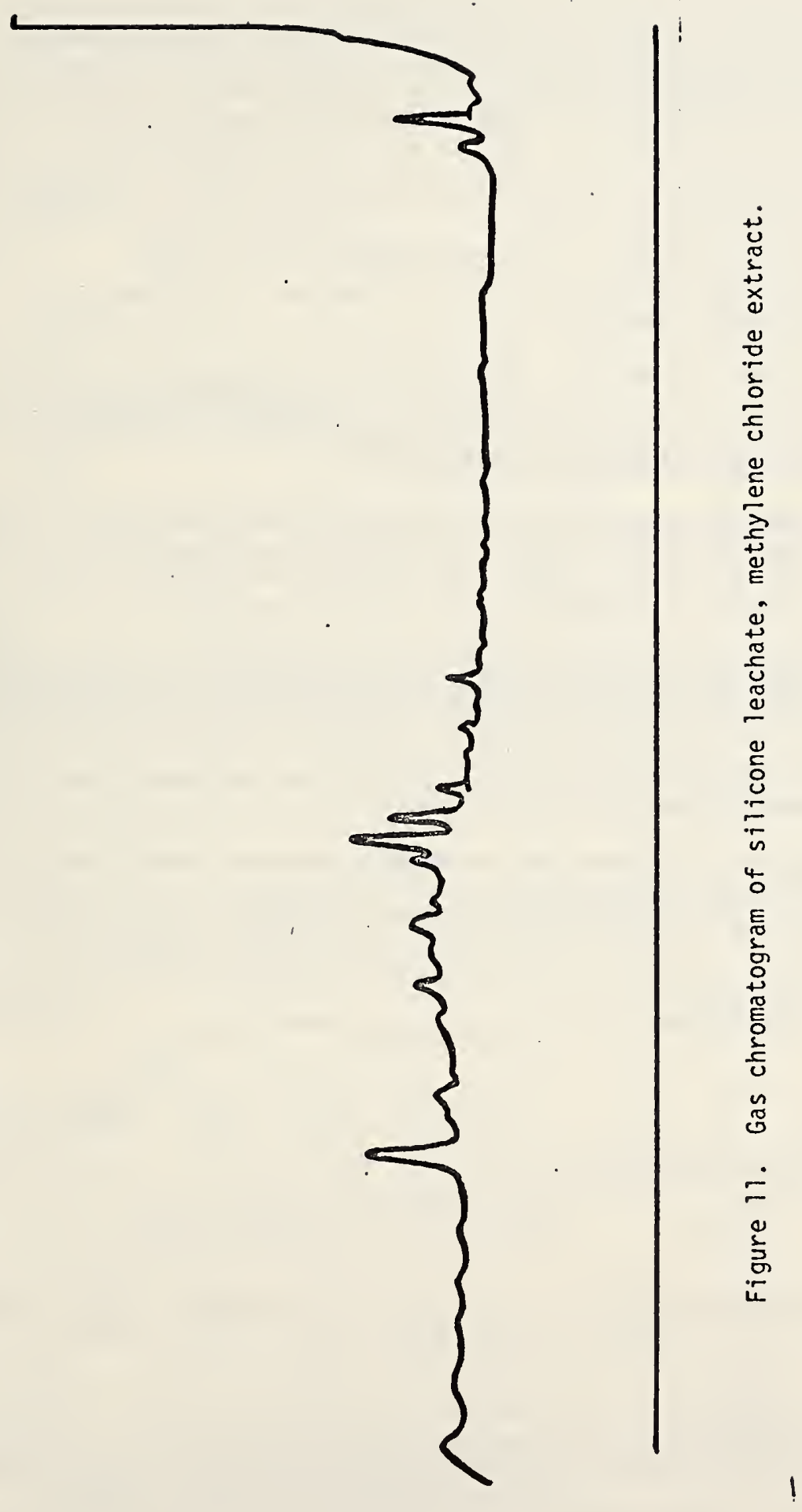


For mass spectrometric analysis, $10 \mu \mathrm{L}$ of the methylene chloride solution was placed in a clean capillary tube, and the solvent removed under house vacuum. The capillary was placed in the direct insertion probe of a mass spectrometer and heated from $50^{\circ}$ to $300^{\circ} \mathrm{C}$ at $30^{\circ} / \mathrm{min}$. Mass spectra were scanned repetitively at 200 mass units per second over the course of the run. Figure 12 shows the total ion current profile and $\mathrm{m} / \mathrm{z} 73,147,207,221,281$ and 295 mass chromatograms versus the probe temperature. The 147-295 mass chromatograms were fragments from a dimethylsilicone. The presence of $\cdot \mathrm{m} / \mathrm{z} 73$ suggests that the ends of the dimethylsiloxane chains are capped with trimethylsilyl groups.

Figure 13 is a representative spectrum of the polymer. The same major ions are observed at all temperatures examined.

As with many polymeric materials, the presence of phthalate esters was observed. Figure 14 (upper) shows the total ion current profile and $\mathrm{m} / \mathrm{z} 149$ mass chromatogram versus probe temperature. At $45{ }^{\circ} \mathrm{C}$, the mass spectrum (Fig. 14, lower) shows the presence of ions characteristic of phthalate esters.

For a second leaching study, $10 \mathrm{~g}$ of the gel and $10 \mathrm{~mL}$ of water were stirred slowly at room temperature for four hours. The leachate was decanted into a flask and the water was evaporated under vacuum. The residue was subjected to gel permeation chromatography (GPC), spectroscopic, GC/MS, and NMR analysis.

A tetrahydrofuran solution of this residue was used for GPC analysis (refractive index detection) which showed two very low, broad peaks, indicating substances with molecular weights of approximately 200 or less. Chemical spectroscopic analysis of the remaining portion of this sample showed the presence of sodium and silicon.

GC/MS analys is confirmed our previous results with no new information being obtained from this leaching experiment.

The leachate studies on silicone gel prompted a series of experiments to examine the silicone gel itself, without leaching. For this purpose, a small amount of the silicone gum was placed on the tip of a clean capillary tube. The capillary tube was heated from 50 to $300{ }^{\circ} \mathrm{C}$ and mass spectra were scanned repetitively every $2 \mathrm{~s}$ during the elution of material. The mass spectra showed the material to be a dimethyl silicone polymer of the type:
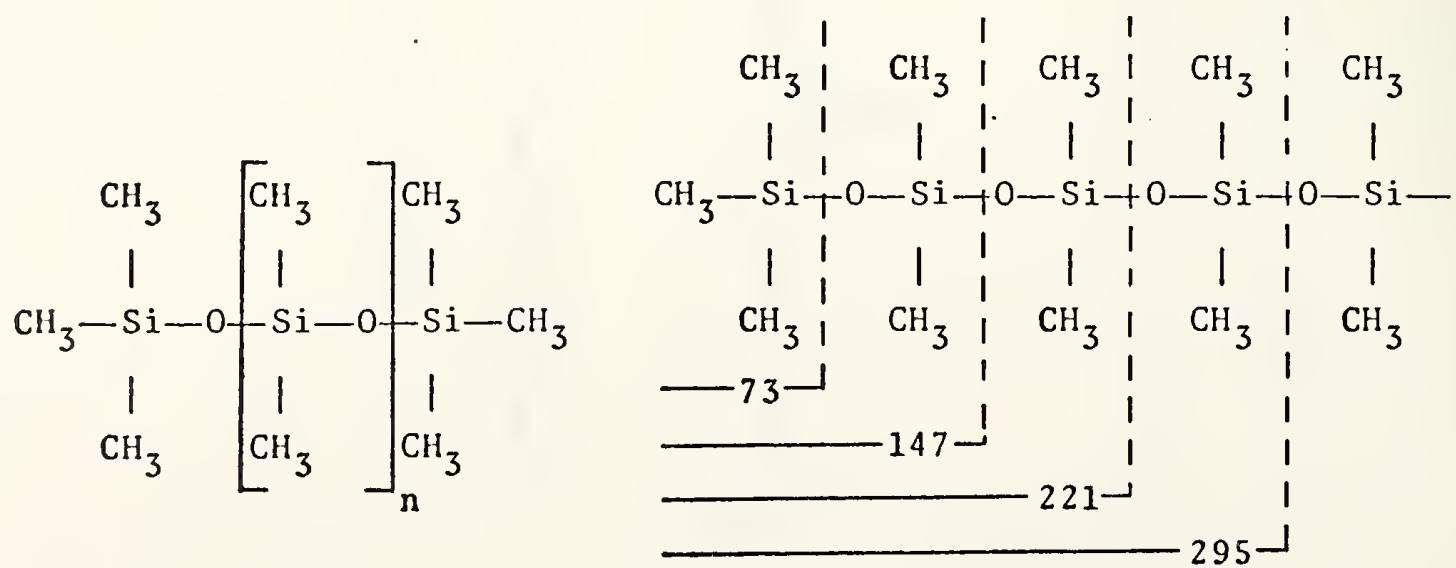

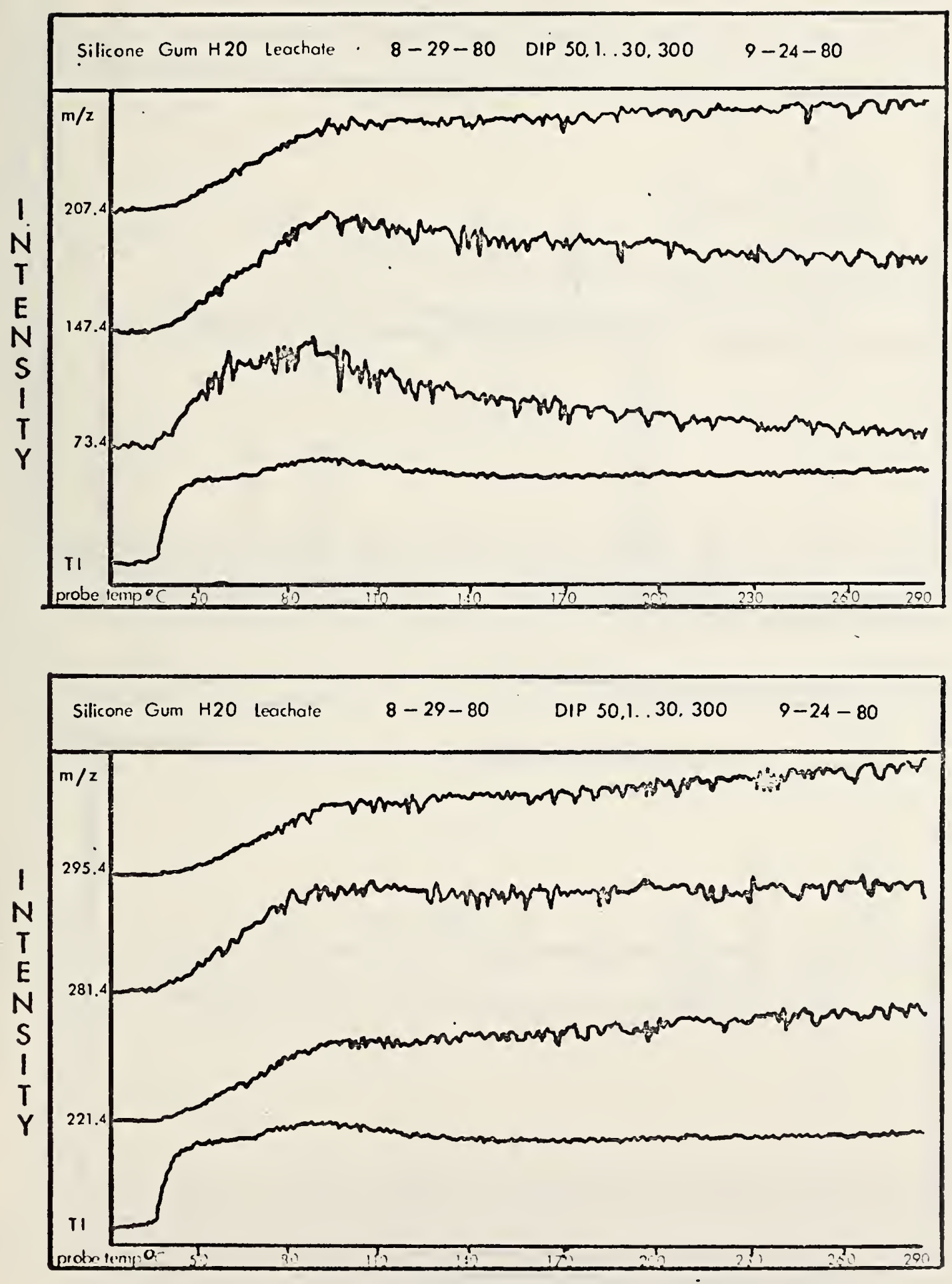

- Figure 12. Total ion current, $\mathrm{m} / \mathrm{z} 73,147,207,221,281$ and $295 \mathrm{vs.} \mathrm{probe} \mathrm{tempera-}$ ture for silicone gel. 

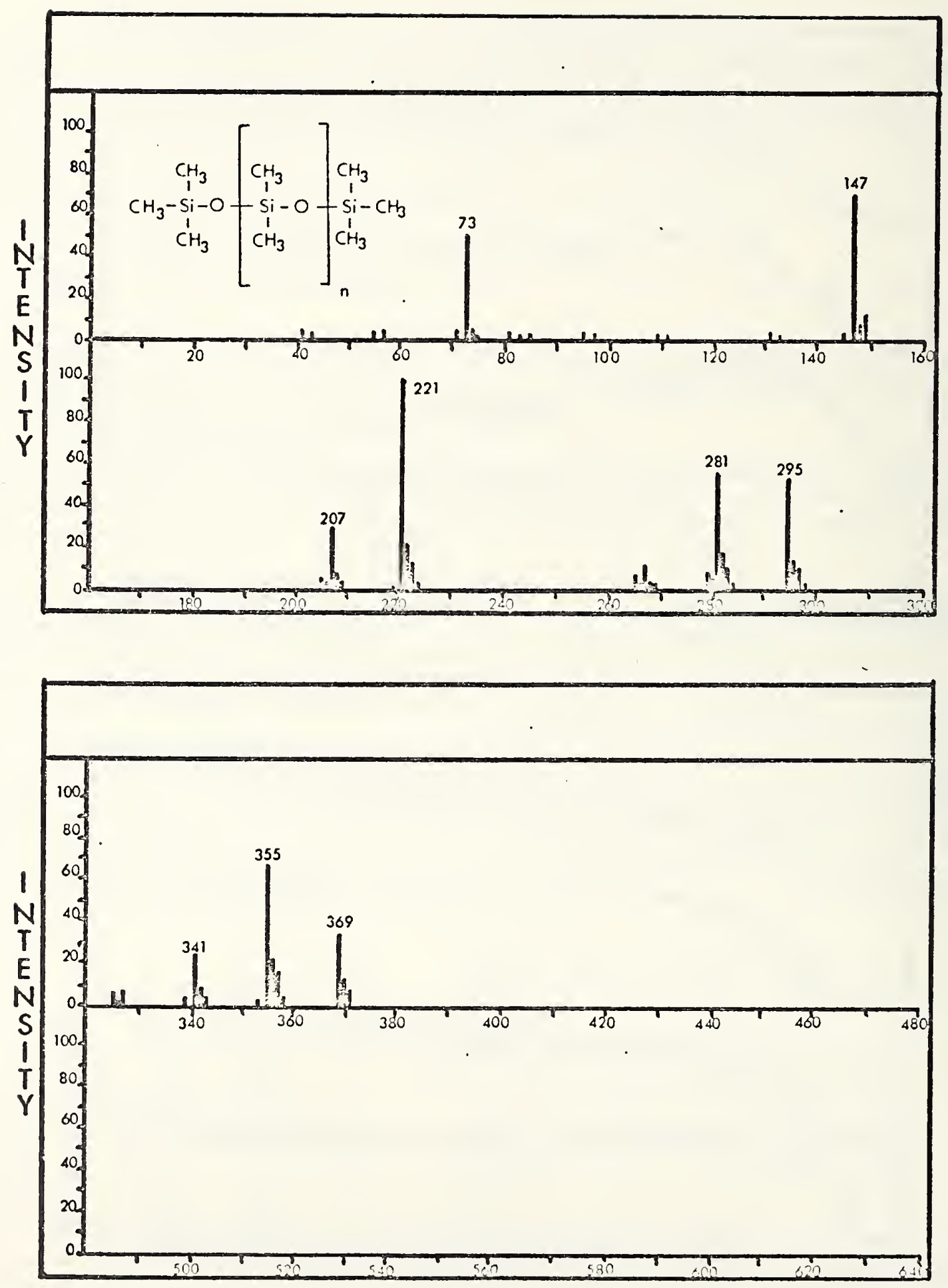

Figure 13. Mass spectrum at a probe temperature of $90^{\circ} \mathrm{C}$, silicone gel leachate. 

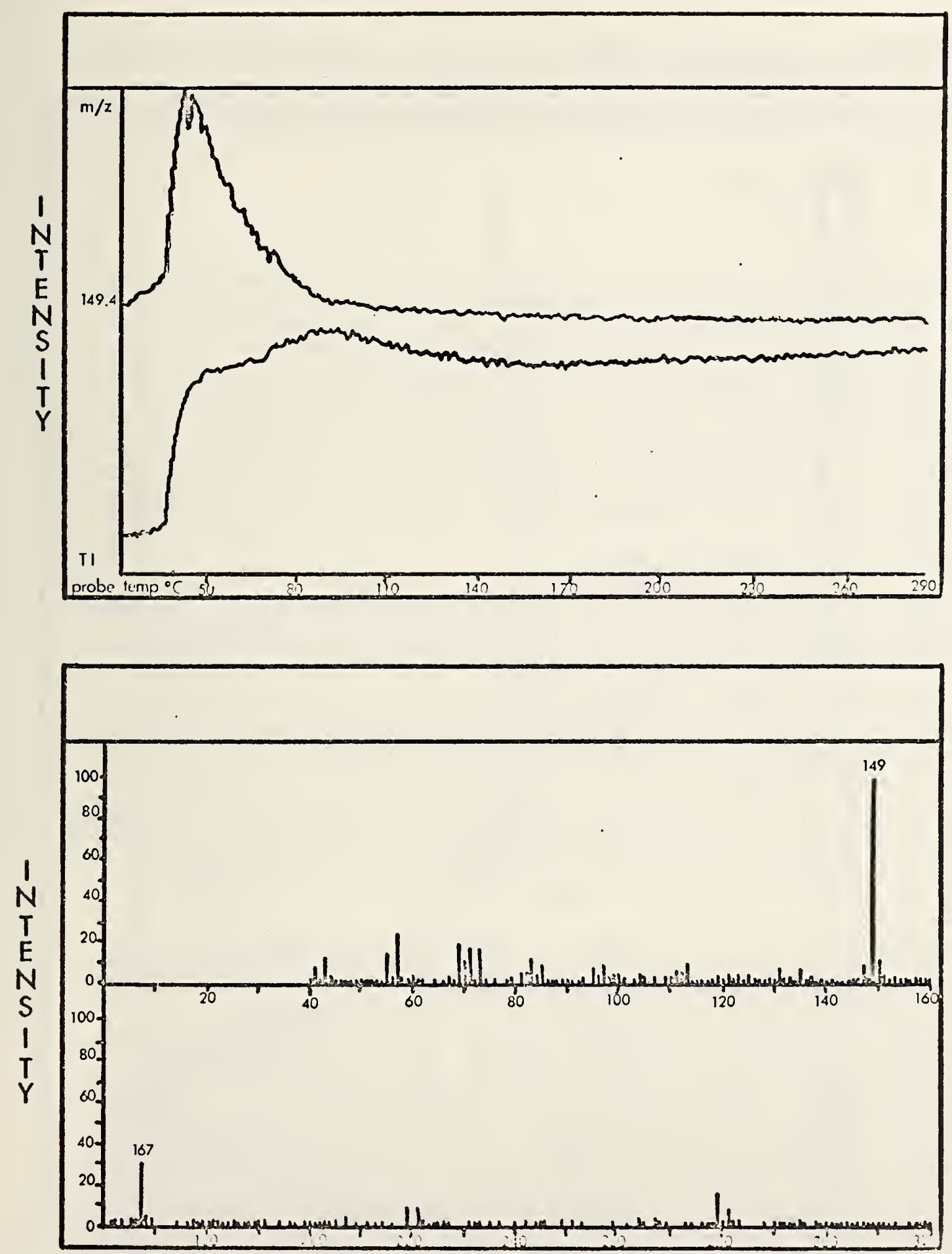

- Figure 14. (upper) Total ion current and $\mathrm{m} / \mathrm{z} 149 \mathrm{vs}$. probe temperature for silicone gel leachate. (lower) Mass spectrum at probe temperature of $45{ }^{\circ} \mathrm{C}$ showing the presence of ions characteristic of phthalate esters. 
Mass chromatograms for characteristic ions for the methyl silicone polymer $(\mathrm{e} . \mathrm{g} ., \mathrm{m} / \mathrm{z}$ $73,147,221$ and 295) show the same elution profile as the total ion current trace. Spectra obtained near the beginning and end of the run are similar, al though there are some differences in relative abundances of some of the ions. Results are shown in figures $15-17$.

\subsection{Prolyl Hydroxylase Studies}

\subsubsection{Enzyme Preparation}

Prolyl hydroxylase was prepared by the method of Bentley and Weiser [11] from $10,000 \times g$ supernatant fractions of the homogenates of 10 day old eviscerated chick embryos. After evisceration, chicks were weighed, cut up with scissors and homogenized with extraction buffer in a homogenizer obtained from Bellco Glass, Inc.

(Vineland, N.J. 08360). Half a gram of chick was extracted with $2 \mathrm{~mL}$ of extraction buffer which contained $0.23 \mathrm{~mol} / \mathrm{L}$ sucrose, $9 \mu \mathrm{mol} / \mathrm{L}$ dithiothreitol, $23 \mu \mathrm{mol} / \mathrm{L}$ EDTA, $0.28 \mathrm{mmol} / \mathrm{L} \alpha$-toluene sulfonyl fluoride in tris (hydroxymethyl) aminomethane hydrochloride (TRIS-HCl) ( $\mathrm{pH} 7.5,0.05 \mathrm{~mol} / \mathrm{L})$. The homogenate was centrifuged at $10,000 \times$ $\mathrm{g}$ for $25 \mathrm{~min}$ at $4{ }^{\circ} \mathrm{C}$. The supernatant liquid was used as the enzyme solution and stored in a deep freeze at $20^{\circ} \mathrm{C}$. Five hundred $\mathrm{mL}$ of this crude enzyme preparation were prepared and some of it has been used for tests and for purification attempts.

\subsubsection{Protocollagen Substrate Preparation}

a. Initial enzyme substrate was prepared with minor modifications by the method of Hutton, Tappel, and Udenfriend [12]. To 5-6 g of 10-day-old decapitated chick embryos was added $8.5 \mathrm{~mL}$ of buffer which contained $0.022 \mathrm{~mol} / \mathrm{L} \mathrm{NaCl}, 0.003 \mathrm{~mol} / \mathrm{L} \mathrm{KCl}$, $0.0012 \mathrm{~mol} / \mathrm{L} \mathrm{MgSO}_{4}, 0.0013 \mathrm{~mol} / \mathrm{L} \mathrm{CaCl}_{2}, 0.0004 \mathrm{~mol} / \mathrm{L} \mathrm{KH}_{2} \mathrm{PO}_{4}, 0.025 \mathrm{~mol} / \mathrm{L} \mathrm{NaHCO} 3$, $0.01 \mathrm{~mol} / \mathrm{L} \mathrm{D}$-glucose, $1 \mathrm{mmol} / \mathrm{L} \alpha$, $\alpha^{\prime}$ dipyridyl and $500 \mu \mathrm{Ci}$ of $L-\left[3,4-{ }^{3} \mathrm{H}\right]$ proline. Ten bottles each containing $8.5 \mathrm{~mL}$ of chick homogenate were incubated aerobically in separate beakers for $90 \mathrm{~min}$ at $37^{\circ} \mathrm{C}$. The contents of the 10 beakers were pooled and centrifuged, and the supernatant liquid was discarded. The pellets were extracted with $0.5 \mathrm{~mol} / \mathrm{L}$ acetic acid $\left(50 \mathrm{~g}\right.$ tissue per $100 \mathrm{~mL}$ acid) for $90 \mathrm{~min}$ at $0{ }^{\circ} \mathrm{C}$. The supernatant liquid from the extraction was dialyzed for 18 hours against three changes of water, and the pellet reextracted with acetic acid and dialyzed also. Typically we obtained $146,000 \mathrm{dpm} / \mathrm{mg}$ of protein for the first extraction and $265 \mathrm{dpm} / \mathrm{mg}$ of protein for the second extraction, with a counting efficiency of 46.3 percent.

b. The substrate preparation procedure of Peterkovsky and DiBlasio was also employed [13]. For this $2.13 \mathrm{~g}$ of frontal bones (calvaria) were obtained from 80 15day-chick embryos. These were incubated with shaking at $37{ }^{\circ} \mathrm{C}$ in $25 \mathrm{~mL}$ of Eagle's minimal essential medium containing $0.5 \mathrm{mmol} / \mathrm{L} \alpha, \alpha^{\prime}$-dipyridyl and $1 \mathrm{mCi}$ of $\mathrm{L}-[3,4-3 \mathrm{H}]$ proline. The solution was chilled to $0^{\circ} \mathrm{C}$, the bones were separated and rinsed with cold $0.11 \mathrm{~mol} / \mathrm{L} \mathrm{NaCl-0.05} \mathrm{mol/L} \mathrm{TRIS-HCl,} \mathrm{pH} 7.4$ containing $1 \mathrm{mmol} / \mathrm{L}$ proline. The bones were homogenized in $24 \mathrm{~mL}$ of $0.5 \mathrm{~mol} / \mathrm{L}$ acetic acid in a Polytron tissue homogenizer for two $15 \mathrm{~s}$ intervals at $0{ }^{\circ} \mathrm{C}$, and the suspension was stored at $4{ }^{\circ} \mathrm{C}$ overnight. It was centrifuged at $20,000 \times \mathrm{g}$ for $30 \mathrm{~min}$, and the supernatant solution was dialyzed against two $3.5-\mathrm{L}$ changes of $0.4 \mathrm{~mol} / \mathrm{L} \mathrm{NaCl}-0.1 \mathrm{~mol} / \mathrm{L}$ TRIS-HCl buffer ( $\mathrm{pH} 7.6)$. The dialyzate was precipitated with ammonium sulfate, the precipitate was dissolved in $11.25 \mathrm{~mL}$ of $0.2 \mathrm{~mol} / \mathrm{L} \mathrm{NaCl}-0.05 \mathrm{~mol} / \mathrm{L}$ TRIS-HCl ( $\mathrm{pH} 7.6$ ) and dialyzed against this buffer. The dialyzed solution was heated at $37^{\circ} \mathrm{C}$ for 1.5 hours to induce precipitation of fibrils. These were removed by centrifugation at $20,000 \times \mathrm{g}$ for $10 \mathrm{~min}$. The radioactive $(16,300 \mathrm{dpm} / \mathrm{mg})$, unhydroxylated, denatured collagen remained soluble and the resultant $10 \mathrm{~mL}$ of solution was stored at $-20{ }^{\circ} \mathrm{C}$ for future use. Use, however, was limited due to the lower specific activity of this preparation. 


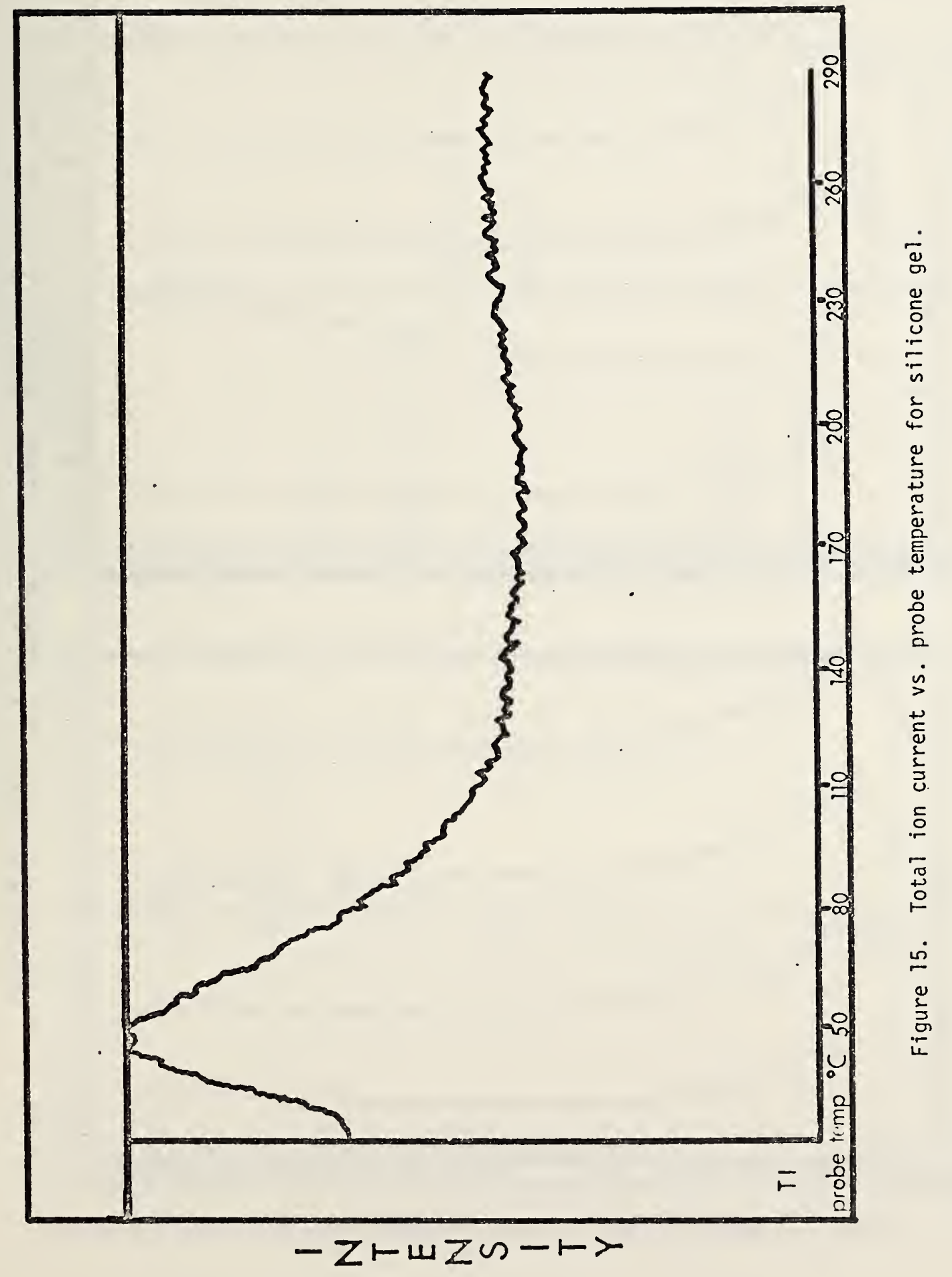




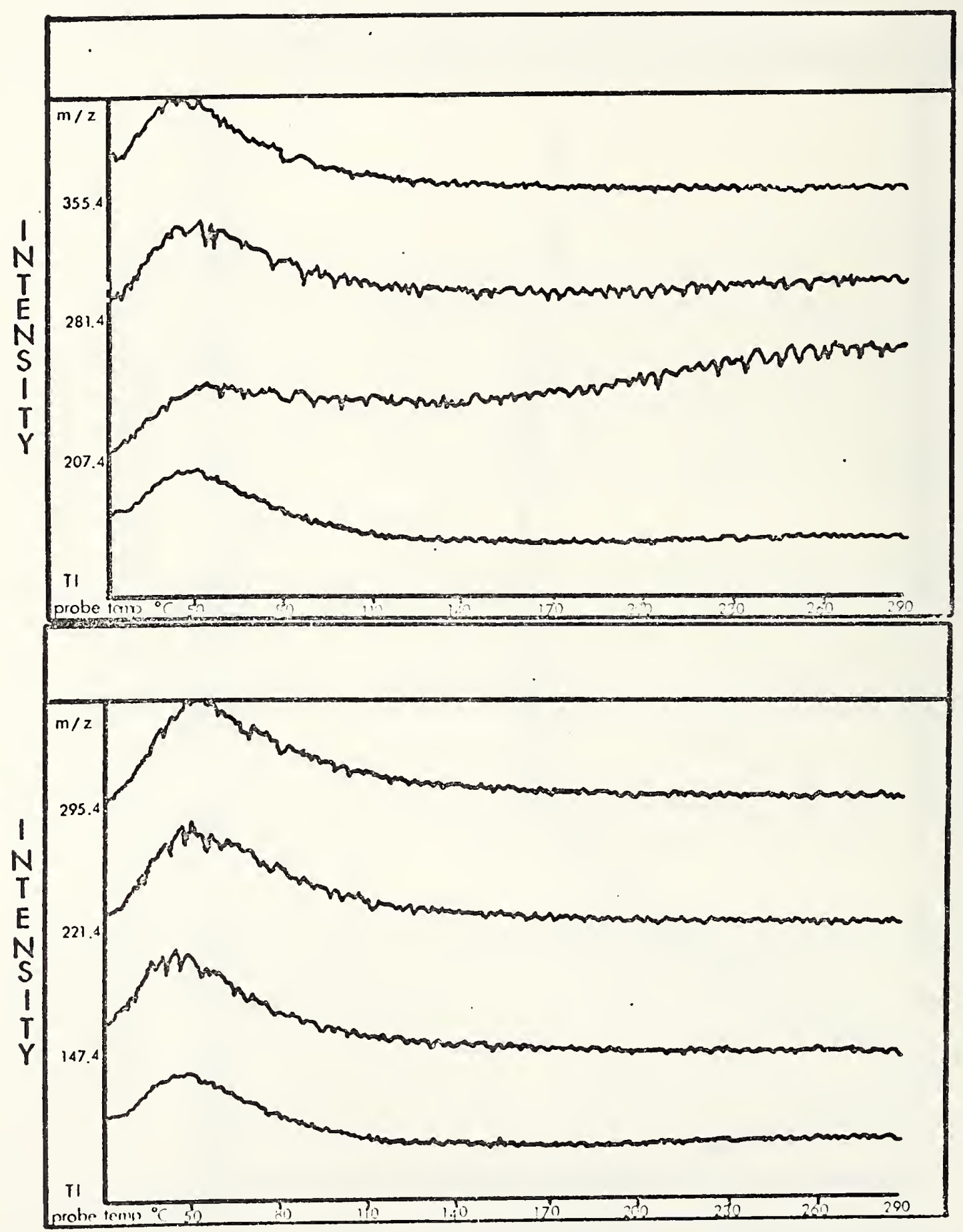

Figure 16. Total ion current and selected mass chromatograms for silicone gel. 

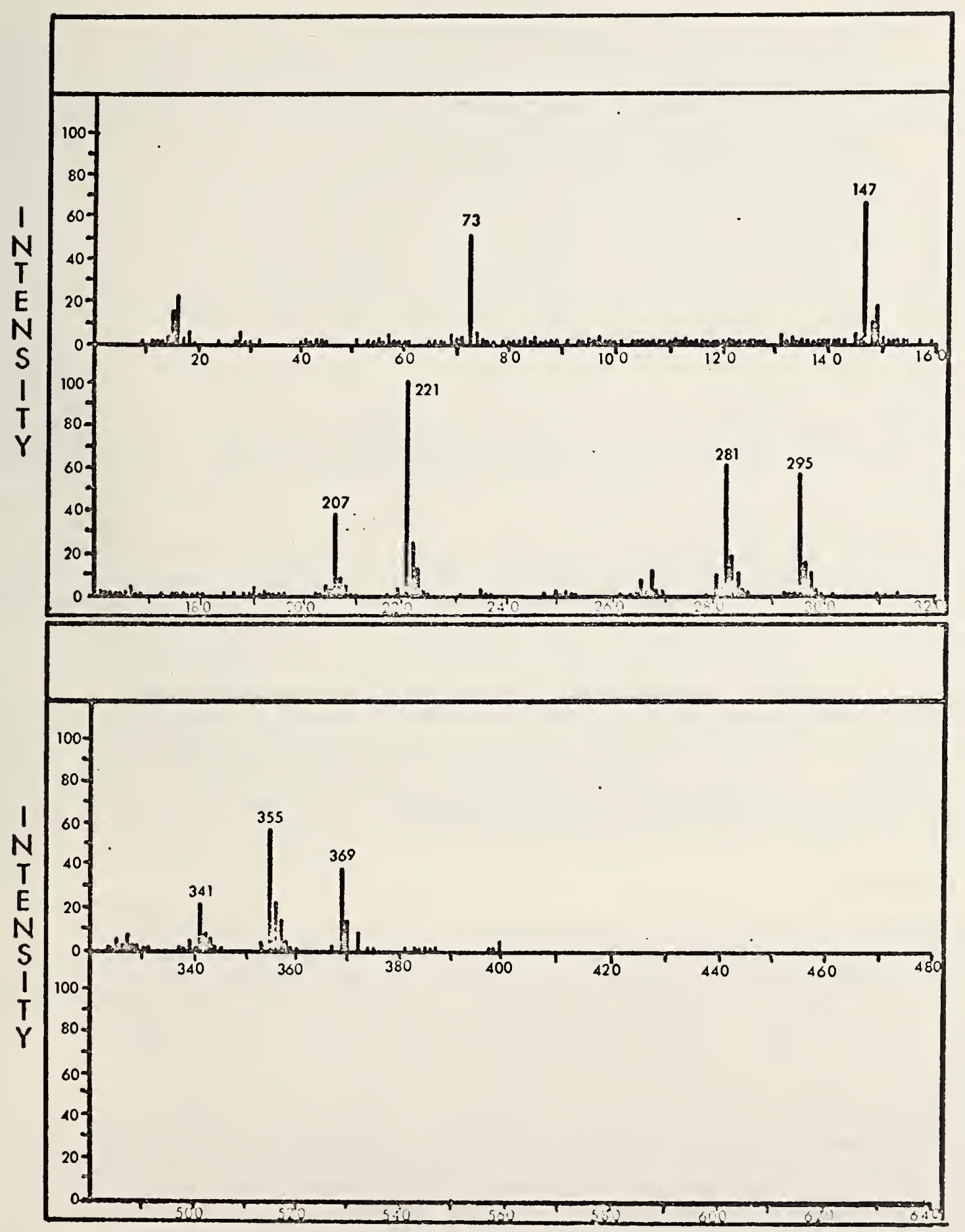

Figure 17. Mass spectrum at probe temperature of $50^{\circ} \mathrm{C}$ (silicone gel). 


\subsubsection{Enzyme Assay}

Enzyme activities were initially measured using the following assay mixture [11]: $0.05 \mathrm{~mL}$ of tritiated protocollagen substrate, $0.1 \mathrm{~mL}$ of enzyme preparation, and $0.05 \mathrm{~mL}$ of cofactor solution. The cofactor solution contained: $2 \mathrm{mmol} / \mathrm{L}$ sodium a-ketoglutarate, $4 \mathrm{mmol} / \mathrm{L} \mathrm{Fe}\left(\mathrm{NH}_{4}\right)_{2}\left(\mathrm{SO}_{4}\right)_{2}, 20 \mathrm{mmol} / \mathrm{L}$ ascorbic acid, $15 \mathrm{mg}$ bovine serum albumin $/ 5 \mathrm{~mL}, 4 \mathrm{mg} / 5 \mathrm{~mL}$ of catalase, and 0.4 percent $\mathrm{V} / \mathrm{v}$ Triton $X-100$. The components were dissolved in $5 \mathrm{~mL}$ of $0.4 \mathrm{~mol} / \mathrm{L}$ TRIS-HCl, $\mathrm{pH} 7.5$ immediately before the assay was to be performed. Typically the reactants were added to ten plastic test tubes $(10 \times 75 \mathrm{~mm})$ and these were capped and shaken in a $37{ }^{\circ} \mathrm{C}$ bath for one hour. The reaction was stopped by addition of $0.02 \mathrm{~mL}$ of 50 percent trichloroacetic acid. Tritiated water from each sample was separated from the other reactants by one of several methods detailed in this section, and placed in a scintillation vial, to which $15 \mathrm{~mL}$ of Aquasol II (New England Nuclear, Boston, MA 02118) were added. Samples were counted in a scintillation counter.

\subsubsection{Conway Cells}

Initialiy we attempted to use the assay method of Bentley and Weiser [11]. For this the tritiated water was separated from the other reactants by placing the reactants into the outer well of a Conway cell. Concentrated sulfuric acid (18.4 $\mathrm{mol} / \mathrm{L}$ ) was placed in the center well to trap the tritiated water. The ceills were covered with a lightly greased, ground glass cover and placed in a $78-85^{\circ} \mathrm{C}$ oven for one hour. The cells were allowed to cool and the center well contents placed in a scintillation vial. The vial contents were frozen by placing the vial in a dry ice acetone bath, $0.70 \mathrm{~mL}$ of $13.4 \mathrm{~mol} / \mathrm{L}$ potassium hydroxide was added, the vial cap quickly replaced, and the neutralization allowed to occur at roon temperature. The vials were placed in a refrigerator for 5-10 min; then $15 \mathrm{~mL}$ of scintillation cocktail were added. After the addition of $\mathrm{KOH}$, we tested the $\mathrm{pH}$ of samples processed according to this procedure and found that it varied from 2 to 12 . Since acidic scintillation samples produce spurious counts, we attempted to refine the technique by making minor procedural modifications such as doing test titrations, changing the reactant volume, etc. However, we were never able to obtain good precision with this technique; at best the relative standard deviation was 12 percent ( $700 \mathrm{cpm}$ ), but there were often samples with count rates three times the value of the mean when the high sample was excluded from calculation of the mean.

\subsubsection{Microstills}

In an attempt to achieve better separation; we built a manifold vacuum still to separate tritiated water from the other reactants. The plastic tubes containing incubated assay samples were connected to $5 \mathrm{~mL}$ capacity traps. The system was designed to allow heating of 14 sample tubes from which distilled water was trapped by dry ice-acetone cooling. Trapped tritiated water was transferred to scintillation vials and counted as before. With this experimental system, blank samples (those containing only cofactor and substrate) typically gave $50 \mathrm{cpm}$, those with enzyme gave $200 \mathrm{cpm}$ (relative standard deviation of 10 percent). Abnormally high sample activities were infrequently seen and were traceable to instances of faulty sample handiing or inadequate cleansing of reused glassware. The principal drawback was that performing the assay was laborious; the distillation step required approximately two hours, and it was found necessary to subject the reused glass parts of the apparatus to acid washing. The low level of tritium recovered was also a disadvantage because long counting periods were required for good statistics. In total, however, the method was reliable and was the method we used for monitoring enzyme activity resulting from various purification procedures. 


\subsubsection{3 $\mathrm{CO}_{2}$ Assay}

Because the distillation assay was time consuming, we attempted to assay enzyme activity by trapping $\mathrm{CO}_{2}$ [14] in a coupled enzyme assay. For this assay we used $0.25 \mathrm{~mL}$ of crude enzyme preparation, $0.25 \mathrm{~mL}$ of solution containing $0.1 \mathrm{mg}$ of poly(L-prolyl-glycyl-L-proline), (Miles-Yeda Ltd., Elkart, Ind. 46514) and $0.5 \mathrm{~mL}$ of cofactor solution such that the final concentrations of components were: $0.05 \mathrm{mmol} / \mathrm{L}$ $\mathrm{FeSO}_{4}, 0.1 \mathrm{mmol} / \mathrm{L} 2-0 \times 0\left[1-{ }^{14} \mathrm{C}\right]$-glutaric acid (adjusted to a specific activity of $60,000 \mathrm{dpm} / 0.1 \mu \mathrm{mol}), 2 \mathrm{mmol} / \mathrm{L}$ ascorbic acid, $0.1 \mathrm{mg} / \mathrm{mL}$ of catalase, $0.1 \mathrm{mmol} / \mathrm{L}$ dithiothreitol, and $2 \mathrm{mg} / \mathrm{mL}$ bovine serum albumin in $0.05 \mathrm{miol} / \mathrm{L}$ TRIS-HCl (pH 7.8 at $5{ }^{\circ} \mathrm{C}$ ): The peptide substrate was thermally denatured by heating at $100{ }^{\circ} \mathrm{C}$ for 5 min and quenching to $0{ }^{\circ} \mathrm{C}$ immediately prior to addition to the reaction system. Mixed reactants were heated at $37{ }^{\circ} \mathrm{C}$ for $30 \mathrm{~min}$ in cork-capped test tubes. To detect evolved $\mathrm{CO}_{2}$, fluted filter paper $(2.5 \times 10 \mathrm{~cm})$ was impregnated with $0.2 \mathrm{~mL}$ of $1 \mathrm{~mol} / \mathrm{L}$ hyamine hydroxide (Calbiochem, La Jolla, CA). These were inserted into the test tube, $0.2 \mathrm{~mL}$ of $2.5 \mathrm{~mol} / \mathrm{L} \mathrm{H}_{2} \mathrm{SO}_{4}$ was added from a syringe equipped with a long needle and the cork was quickly replaced. The tubes were shaken several times during the half hour $\mathrm{CO}_{2}$ evolution period. Filter papers from the test tubes were added to separate scintillation vials, to which $15 \mathrm{~mL}$ of scintillation fluid was also added. These were counted in the scintillation counter. The entire experiment was repeated a number of times. However, no enzyme activity could be measured reliably by this method because the enzyme preparation was too low in activity.

\subsubsection{Column Separation}

Realizing that the distillation assay was time-consuming and gave a low tritium recovery, we attempted to develop a faster procedure in which the tritiated water would be separated by means of a short chromatography column.

\section{(1) Sephadex G-25}

We made a number of trials with prepacked columns containing G-25 Sephadex. For these the assay mixture described in part (3) (below) was used. For experimental mixtures of substrate and tritiated water, tritium counts in the third mL eluted analyzed $1711 \pm 77 \mathrm{cpm}$ or a relative standard deviation of 4.5 percent. In different assays, however, the tritium activity of the third $\mathrm{mL}$ of eluent varied from 1571 to $5284 \mathrm{cpm}$. If total activity of all three $\mathrm{mL}$ of eluent was considered, the mean value was $17,050 \div 1721$ with a blank value (no enzyme) of $8098 \mathrm{cpm}$. This was not considered adequate as a separation procedure.

\section{(2) Sephadex C-25}

We attempted to make a separation on C -25 Sephadex, a cation exchange gel, after treating the gel with acid to replace bound sodium. The tritiated water was eluted after the tritium-labeled substrate, as it had been from G-25 Sephadex, making consistent collection of tritiated water in a specified fraction impossible.

\section{(3) Bio-Rad AG 50W-X8}

Due to our unsuccessful attempts to separate tritiated water satisfactorily with Sephadex, we decided to try the assay method of Peterkovsky [13] which makes use of Bio-Rad $A G 50 \%-X 8$ as column packing material. For this assay the final volume of the reacting mixture is $100 \mu \mathrm{L}$ of which $15 \mu \mathrm{L}$ is $\mathrm{L}-[3,4-3 \mathrm{H}]$ proline-labeled substrate (denatured for 15 min at $37^{\circ} \mathrm{C}$ prior to addition), $60 \mu \mathrm{L}$ of enzyme and $25 \mu \mathrm{L}$ of cofactor solution containing: $1 \mathrm{mmol} / \mathrm{L}$ sodium ascorbate, $1 \mathrm{mmol} / \mathrm{L}$ sodium $\alpha$-ketoglutarate, 0.2 mmol/L ferrous ammonium sulfate, $0.4 \mathrm{mg} / \mathrm{mL}$ catalase, $2 \mathrm{mg} / \mathrm{mL}$ bovine serum albumin, and $0.5 \mathrm{mmol} / \mathrm{L}$ dithiothreitol dissolved in TRIS-HCl $(0.04 \mathrm{mmol} / \mathrm{L}, \mathrm{pH} \mathrm{7.6)}$. 
The reactants were incubated for 15 min at $37^{\circ} \mathrm{C}$, then the reaction was stopped by addition of $0.4 \mathrm{~mL}$ of 6.25 percent trichloroacetic acid. Fifteen $\mu \mathrm{L}$ of $25 \mathrm{mg} / \mathrm{mL}$ bovine serum albumin was added to. each tube, reactants were mixed, allowed to stand for $5 \mathrm{~min}$ at $0{ }^{\circ} \mathrm{C}$ and centrifuged at $1.5 \mathrm{~g}$ for $5 \mathrm{~min}$. The supernatant liquid was removed, an additional $0.5 \mathrm{~mL}$ of 5 percent trichloroacetic acid was added to the resuspended pellets, and the mixture centrifuged as before. The supernatant portions were combined and added to small chromatography columns $(0.5 \times 2 \mathrm{~cm})$. Scintillation vials were used to collect the effluent and $0.5 \mathrm{~mL}$ of water wash. Scintillation fluid ( $15 \mathrm{~mL}$ ) was added and the solutions counted. Blank solution (containing no enzyme) gave a count rate of $28.5 \pm 2.5 \mathrm{cpm}$, whereas assay mixtures gave a rate of $85.3 \pm 9.6$. Longer counting times than $10 \mathrm{~min}$ for these samples would have yielded smaller standard deviations. Since we desired larger count rates, we tested the separation with Bio-Rad $A G 50 \mathrm{~W}$ by adding mixtures containing $50 \mu \mathrm{L}$ of substrate and $50 \mu \mathrm{L}$ of tritiated water. These were placed on the column, rinsed through with $1 \mathrm{~mL}$ of water and collected. An additional $1.5 \mathrm{~mL}$ of water was added, collected and counted as a second fraction. The second fraction contained about 95 percent of the activity; however, the count rate for the second sample varied from 1367 to $1648 \mathrm{cpm}$. When the percent of the activity of both eluted fractions was calculated it was found that 94.5 percent \pm 0.9 percent was in the second sample. We believe this separation method provides a basis for a suitable assay technique.

\subsubsection{Enzyme Purification}

\subsubsection{Sepharose 4-B}

Chromatography of a crude prolyl hydroxylase ammonium sulfate fraction (30-65 percent) on a Sepharose $4 \mathrm{~B}$ column with buffer consisting of $0.1 \mathrm{~mol} / \mathrm{L} \mathrm{NaCl}$, $0.1 \mathrm{~mol} / \mathrm{L}$ glycine, $10 \mathrm{mmol} / \mathrm{L}$ dithiothreitol, $0.01 \mathrm{~mol} / \mathrm{L}$ TRIS-HCl (pH $7.8,4{ }^{\circ} \mathrm{C}$ ) yielded enzyme with specific activity increased 13,000 times. However, all activity was lost after storage at $-12{ }^{\circ} \mathrm{C}$ for one week.

\subsubsection{Dye Ligand Chromatography}

Promising results were obtained from an initial experiment in which we attempted to enhance.enzyme specific activity by use of dye-ligand chromatography (Amicon Corp., Lexington, MA). Enzyme activity was doubled when it wa's eluted from a gel matrix to which Blue $A$ was bound. However, we have not been able to duplicate these results in a larger scale system.

\subsubsection{Affinity Chromatography}

Affinity chromatography was also employed for enzyme purification [14]. To assess the efficiency of the coupling method used in preparing the affinity columns, we performed amino acid analysis on a sample of the proline-labeled gel. Analysis indicated 13 percent $w / w$ proline, suggesting that attachment of the poly-L-proline (Type IV, MW $>30,000$ ) to the gel was successful.

Prior to addition to the affinity column, crude enzyme solutions were purified by ammonium sulfate fractionation of $100 \mathrm{~mL}$ of the crude preparation. The precipitate from 30-85 percent saturation was redissolved in $25 \mathrm{~mL}$ of buffer, and then dialyzed against $0.1 \mathrm{~mol} / \mathrm{L}$ glycine, $0.1 \mathrm{~mol} / \mathrm{L} \mathrm{NaCl}$ in buffer $(0.05 \mathrm{~mol} / \mathrm{L}$ TRIS- $\mathrm{HCl}$, $\mathrm{pH} 7.8,4{ }^{\circ} \mathrm{C}$ ). The $35 \mathrm{~mL}$ of dialyzate, which was found to have a $230 \mathrm{~nm}$ absorbance of 12.8 , indicating a protein concentration of $\sim 10 \mathrm{mg} / \mathrm{mL}$, was added to the affinity column. For the first trial with the affinity column, $5 \mathrm{~mL}$ of dialyzate was added to the column. In later trials larger amounts were added, e.g., $35 \mathrm{~mL}$. The enzyne was extracted from the colunin with poly-L-proline, type II. Poly-L-proline was separated from the enzyme by rinsing the enzyme containing portions of the eluent through a 
Bio-gel column (A 1.5, 200-400 mesh). Enzyme containing eluent from the Bio-gel column was concentrated by use of an Amicon filter. Initially the enzyme had a net activity of $155 \mathrm{cpm}$ (assay by distillation); after the affinity procedure and concentration, the most active fraction produced an activity of $70 \mathrm{cpm}$, and a protein concentration of $0.02 \mathrm{ng} / \mathrm{mL}$. Three repetitions of this experiment gave the same result; most of the enzyme activity was lost when the extraneous prote in was renoved. other investigators have also found prolyl hydroxylase to be unstable when purified. Therefore added protein may be necessary for stabilization.

\section{Discussion and Conclusions}

Identification of the leachate content from the four polymeric substances has not been completed, al though a number of substances have been identified. However, it appears certain that the silicone gel leachate contains a low molecular weight dimethylsiloxane polymer and a phthalate ester. More definitive measurements need to be made to determine the influence of leachate on the enzymatic activity.

He have identified some minor components which leach from polyurethane into water. These are ethyleneurea, 2-ethylhexanoic acid, and a phthalate ester. No methylenedianaline (MDA) was detected, although this doesn't preclude that MDA was present in the polymers. The long-term extraction procedures that we used were not suitable for preservation of MDA in the leachate if it were present. Experiments are planned in which extraction is performed with ethyl ether and where the methylene chloride extraction is el iminated.

We found that a tan-white substance leaches from a particular lot of polyethylene blood bags. We have not yet been able to identify this material. Collection of more material and further identification by infrared and other methods is planned for the next series of experiments.

Identification of components leaching from polycarbonate was assigned the lowest priority. Preliminary work with polycarbonate indicates low molecular weight leachables are present.

Leaching experiments of the polymers with physiological saline and Eagles minimal essential media are indicated as an extension of studies already performed.

Results of these experiments provide an additional basis for evaluating the suitability of the materials tested for their intended medical applications, adding to the body of inforniation which can be used as a basis for making better decisions regarding polynier use.

\section{References}

[1] Hench, L. L. Biomaterials. Science 208: 826-831; 1980.

[2] Homsy, C. A.; Ansevin, K. D.; O'Bannon, W.; Thompson, S. A.; Hodge, R.; Estrella, M. E. Rapid in vitro screening of polymers for biocompatibility. Biomedical Polymers, A. Rembaron and M. Shen, eds. New York, NY: Marcel Dekker; 1971. 121ff.

[3] Thompson, R. M.; Howard, C. C.; Brewer, E. J.; DeRoos, F. L.; Hattery, G. R.; Leininger, R. I. unpublished report, Battelle, Columbus Laboratories, Columbus, Ohio; 1979. 
[4] Lefaus, R. Practical Toxicology of Plastics. London: ILIFFE Books, Ltd.; 1968.

[5] Schabron, J. F.; Fenska, L. E. Determination of BHT, Irganox 1076, and Irganox 1010 antioxidant additives in polyethylene by high performance liquid chromatography. Anal. Chem. 52: 1417-1415; 1980.

[6] Lehotay, J.; Danecek, J.; Liska, 0.; Lesko, J.; Brandsteterova, E. Analytical study of the additives system in polyethylene. J. Appl. Polym. Sci. 25(9): 1943-1950; 1980.

[7] Kandpa 1, L. D.; Tewary, A. K.; Balakrishna, K. J. Leachility of moulded polyethylene. Indian J. Technol. 14(7): 359; 1976.

[8] Darby, T. D.; Johnson, H. J.; Northup, S. J. J. Toxicol. \& Appl. Pharmac. 46: $449-453 ; 1978$.

[9] Lattimer, R. P.; Welch, K. R. Direct analysis of polymer chemical mixtures by field desorption mass spectroscopy. Rubber Chemistry and Technology 53(1): 151-159; 1980.

[10] Autian, J. Toxicology of Degradation Products of Plastics, in Corrosion and Degradation of Implant Materials. ASTM STP 684, B. C. Syrett and A. Acharyo, eds., American Society for Testing and Materials; 1979. 5-19.

[11] Bentley, J. P.; Weiser, K. A. A simple microassay of Prolylhydroxylase applicable to skin punch biopsy specimens. Conn. Tissue Res. 4: 255-259; 1976.

[12] Hutton, J. J.; Tappel, A. L., Jr.; Undenfriend, S. A rapid assay for collagen proline hydroxylase. Anal. Biochem. 16: 384-394; 1966.

[13] Peterkovsky, B.; DiBlasio, R. Modification of the tritium-release assays for prolyl and lysyl hydroxylases using Dowex-50 columns. Anal. Biochem. 66: 274$286 ; 1975$.

[14] Tuderman, L.; Kuuti, E.-R.; Kivirikko, K. I. An affinity column procedure using poly(L-proline) for the purification of prolyl hydroxylase. Eur. J. Biochem. 52: $9-16 ; 1975$. 
NBS-114A (REV. 2-8C)

\begin{tabular}{|c|c|c|c|}
\hline $\begin{array}{c}\text { NBS-114A (REV. 2-BC) } \\
\text { U.S. DEPT. OF COMM. } \\
\text { BIBLIOGRAPHIC DATA } \\
\text { SHEET (See instructions) }\end{array}$ & $\begin{array}{l}\text { 1. PUBLICATION OR } \\
\text { REPORT NO. } \\
\text { NBSIR 81-2436 }\end{array}$ & 2. Performing Organ. Report No. & 3. Publication Date \\
\hline
\end{tabular}

4. TITLE AND SUBTITLE

Low Molecular Weight Leachables from Medical Grade Polymers

5. $\operatorname{AUTHOR}(S)$

B. F. Howell, S. Chesler, L. Hilpert, and D. J. Reeder

6. PERFORMING ORGANIZATION (If joint or other than NBS, see instructions)

NATIONAL BUREAU OF STANDARDS

DEPARTMENT OF COHMERCE

WASHINGTON, D.C. 20234

9. SPONSORING ORGANIZATION NAME AND COMPLETE ADDRESS (Street, City, Stote, ZIP)

7. ContracVGrant No.

8. Type of Report \& Period Covered

10. SUPPLEMENTARY NOTES

[ Document describes a computer program; SF-185, FIPS Software Summary, is attached.

11. ABSTRACT (A 200-word or less factual summary of most significant information. If document includes a significant bibliography or literature survey, mention it here)

Four medically important polymeric materials (silicone polymer from mammary prostheses, polyurethane, polyethylene, and polycarbonate) were placed in contact with water for time periods ranging from four hours to seven days. Substances leaching into water were separated by extraction with methylene chloride, or by evaporation of water, and identification of species in the leachate was attempted by a number of analytical techniques, with extensive use of combined gas chromatography/mass spectrometry (GC/MS). Low molecular weight fragments of dimethylsiloxane were identified from mammary prosthesis gel. Spectra are also included for leachate from the other three polymers; identification of these compounds is still in process.

Prolyl hydroxylase and tritium-labeled protocollagen substrate were prepared from chick embryos, and an enzyme activity assay system was developed with use of Bio-Rad AG 50W-X8 cation exchange resin. No effect on enzyme activity was seen when silicone gel leachate was added to the assay mixture.

12. KEY WORDS (Six to twelve entries; alphabetical order; capitalize only proper names; and separate key words by semicolons) enzymatic assay; gas chromatography/mass spectrometry; leachables; mammary prosthesis; polymeric implants; prolyl hydroxylase

13. AVAILABILITY

[X] Unlimited

$\square$ For Official Distribution. Do Not Release to NTIS

[ Order From Superintendent of Documents, U.S. Government Printing Office, Washington, D.C. 20402.

[X] Order From National Technical Information Service (NTIS). Springfield, VA. 22161
14. NO. OF

PRINTED PAGES

36

15. Price

$\$ 7.50$ 


